\title{
EL ESTATUTO DE ROMA ANTE EL TRIBUNAL CONSTITUCIONAL CHILENO*
}

Antonio Bascuñán Rodríguezt

Rodrigo P. Correa G. $\$$

I. Introducción; II. Tratados y Constitución. III. Jurisdicción de la Corte Penal Internacional: A. Transferencia de soberanía jurisdiccional: 1. Prohibición de transferir soberanía: a) Prohibición de transferir soberanía a órganos no constitucionales; b) Prohibición de transferir soberanía a órganos no estatales; 2. La soberanía jurisdiccional territorial; 3. Excepciones al principio de complementariedad en el Estatuto de Roma: a) Litis pendentia; b) Res iudicata; c) Órgano que decide la admisibilidad; d) Obligación de investigar y juzgar a que está sujeto Chile de conformidad con el derecho internacional; 4. Consecuencias del fallo jurisdiccional: a) Reconocimiento de jurisdicciones no chilenas para conocer y juzgar delitos ocurridos en Chile; b) Reconocimiento de jurisdicciones no chilenas para conocer y juzgar asuntos civiles ocurridos en Chile; c) Tribunales chilenos sin reconocimiento constitucional que no pertenecen al Poder Judicial; B. Transferencia de potestad legislativa para declarar indultos y amnistias generales; C. Transferencia de potestad presidencial para conceder indultos particulares.IV. Conclusión.

\section{Introducción}

Tres días antes de que entrara en vigencia el Estatuto de Roma de la Corte Penal Internacional (CPI), el Tribunal Constitucional chileno lo declaró inconstitucional. ${ }^{1}$ Para hacerse parte del tratado Chile deberá previamente reformar su Constitución Política.

El Tribunal declaró inconstitucional la jurisdicción de la CPI, su potestad para reducir sentencias, la improcedencia del cargo oficial y la potestad del fiscal para llevar a cabo investigaciones en territorio chileno. Salvo en lo que respecta a la potestad del fiscal de la CPI, el Tribunal estimó que en cada uno de los demás casos había más de una inconstitucionalidad. El Tribunal presenta todas estas inconstitucionalidades como independientes entre sí: cada una de ellas habría sido suficiente para declarar inconstitucional el Estatuto. Este comentario sólo analiza el razonamiento del Tribunal en relación con la jurisdicción de la CPI. Se tiene para ello presente que el mayor esfuerzo argumentativo del Tribunal se centró precisamente en esa cuestión, y que sus consecuencias en diversas áreas del derecho chileno son significativas.

Para conocer del recurso interpuesto el Tribunal debió despejar previamente algunas cuestiones relativas a la relación entre los tratados internacionales, la ley y la Constitución Política. La siguiente sección discute la premisa de ese contexto de análisis, a saber, la calificación del Estatuto de Roma a la luz del Art. $5^{\circ}$ de la Constitución chilena.

\footnotetext{
† Profesor asistente, Facultad de Derecho, Universidad de Chile.

$\ddagger$ Profesor asistente. Investigador, Centro de Estudios de la Justicia, Facultad de Derecho, Universidad de Chile.

1 Tribunal Constitucional, sentencia de 8 de abril de 2002, rol 346.
} 


\section{Tratados y Constitución}

Para someter a control de constitucionalidad del Estatuto de Roma, era necesario resolver previamente cuál era su relación con la Constitución Política. Tal control presupone que los tratados internacionales tengan un rango jerárquico inferior al de la Constitución Política. El Tribunal estimó que este presupuesto no era evidente y que su afirmación exigía justificación. Ello lo llevó a pronunciarse acerca de la controversia en torno a la correcta interpretación del inciso segundo del Art. $5^{\circ}$ de la Constitución:

Como es sabido, dentro de los múltiples problemas interpretativos y de dogmática constitucional que genera el principio de la soberanía limitada por el respeto de los derechos fundamentales, consagrado en el precepto antedicho, se encuentra la cuestión de cuál sea el rango jerárquico que quepa reconocer a los tratados internacionales sobre derechos humanos. Una postura interpretativa sostiene que esta clase de tratados internacionales tendría, como mínimo, un rango jerárquico igual al de las normas constitucionales. La consecuencia de esta tesis es que en caso de antinomia entre una norma constitucional y una norma internacional posterior, primaría ésta por derogación tácita de aquella. Y, por lo mismo, que respecto de esta clase de tratados internacionales sería improcedente el control de constitucionalidad.

En sus considerandos $59^{\circ}$ a $73^{\circ}$, el Tribunal Constitucional rechaza esta interpretación, sosteniendo que todo tratado internacional se encuentra jerárquicamente subordinado a la Constitución. Esta argumentación del Tribunal implícitamente concede que el Estatuto de Roma sea un tratado internacional que garantiza derechos esenciales que emanan de la naturaleza humana. Si no fuera así, no habría sido necesario discutir el estatus de esa clase de tratados para proceder a efectuar el control de su constitucionalidad. Pero, ¿es el Estatuto de Roma un tratado internacional sobre derechos humanos?

El Estatuto de Roma crea una nueva jurisdicción penal, la de la Corte Penal Internacional. Define su ámbito de competencia mediante la tipificación de ciertos comportamientos y el establecimiento de ciertas penas, consagra principios generales de atribución de responsabilidad penal, determina la organización de la Corte y el procedimiento para sus actuaciones. En suma, es un tratado internacional punitivo, tanto en lo sustantivo como en lo procesal. Desde el punto de vista del sentido de sus disposiciones, es un cuerpo de normas análogo a lo que sería una mixtura del Código Penal, el Código Orgánico de Tribunales y el Código Procesal Penal. Estos no son cuerpos normativos que consagren derechos fundamentales, como lo es la Constitución. El Estatuto de Roma tampoco es un tratado internacional sobre derechos humanos, como sí lo son, por ejemplo, el Pacto Internacional de Derechos Civiles y Políticos y el Pacto de San José de Costa Rica.

Esta no es una cuestión meramente conceptual o terminológica. Las normas que consagran derechos fundamentales establecen una relación normativa entre el titular de esos derechos (las personas) y el destinatario de los deberes correlativos (preferentemente, los agentes del Estado), tal que a éstos les está prohibido constreñir a aquél a omitir o a realizar ciertas acciones, o les está prohibido afectar el goce por aquél de determinados estados de cosas o condiciones, o por último, les está mandado realizar acciones orientadas a la satisfacción de ciertos intereses de aquél. En suma, las reglas sobre derechos fundamentales reconocen intereses personales y establecen normas de comportamiento. 
Las normas punitivas son de una naturaleza muy distinta. Son normas que amenazan con irrogar un mal para satisfacer alguna finalidad de protección, o bien para reforzar la vigencia de una norma de comportamiento. La norma punitiva, por lo tanto, usa como medio la afectación de alguno de los derechos reconocidos a la persona como intereses fundamentales (básicamente, la libertad y la intimidad). En suma, el ejercicio de las potestades de crear y aplicar normas punitivas es una fuente de peligro para los derechos fundamentales. No es casual que el núcleo histórico originario del desarrollo de las normas sobre derechos fundamentales se encuentre en las garantías del individuo frente a la potestad punitiva del Estado.

Esta es la razón profunda que impide, por un imperativo elemental de justicia política y de congruencia dogmática, considerar al Estatuto de Roma como una convención sobre derechos humanos. La misma razón exige considerar al Estatuto de Roma como subordinado a la Constitución ( $y$, en su caso, a los tratados internacionales que garantizan derechos fundamentales). Tal como el derecho penal nacional, el derecho penal internacional debe ser considerado como esencialmente necesitado de legitimación. Esta legitimación se logra mediante su estricta sujeción a las exigencias garantistas del derecho constitucional y el derecho internacional de los derechos humanos ${ }^{2}$. En un ordenamiento jurídico jerarquizado, este deber de sujeción se expresa asignando a las normas punitivas y de jurisdicción y procedimientos penales un rango inferior al rango de las normas sobre derechos fundamentales.

En conclusión, la consideración del Estatuto de Roma como un cuerpo normativo de rango jerárquico inferior a la Constitución es enteramente correcta. El fundamento de ello, sin embargo, no se encuentra en ninguna de las razones invocadas por el Tribunal Constitucional.

\section{Jurisdicción de la Corte Penal Internacional}

El Tribunal declaró que la jurisdicción de la CPI resulta contraria a la Constitución Política porque importa transferencia inconstitucional de la soberanía nacional. Tres serían las transferencias inconstitucionales: (1) la transferencia de una parte de la jurisdicción de los tribunales nacionales; (2) la transferencia de parte de la potestad legislativa para declarar indultos y amnistías generales, y (3) la transferencia de la potestad presidencial para conceder indultos particulares. Aunque el Tribunal trata conjuntamente estos dos últimos fundamentos, el análisis que sigue mostrará la utilidad de tratarlos por separado.

Antes de analizar el fallo, conviene explicar brevemente cómo se regula la jurisdicción de la CPI. El principio rector es el de complementariedad con las jurisdicciones penales nacionales (párrafo 10 del preámbulo y artículo $1^{\circ}$ ). El Estatuto no ofrece una definición del principio. Sin embargo, el estudio de sus disposiciones permite afirmar que su significado es que la CPI conocerá de los delitos bajo su jurisdicción solo cuando no lo hagan los tribunales nacionales. El artículo 5 del Estatuto confiere a la CPI jurisdicción

2 Para un desarrollo más extenso de esta tesis, y una visión crítica de su distorsión por el derecho penal internacional y un sector de la dogmática constitucional comparada, ver Antonio Bascuñán Rodríguez, "Derechos Fundamentales y Derecho Penal" en Derechos Fundamentales (Buenos Aires: Editores del Puerto, en prensa). 
sobre el crimen de genocidio, los crímenes de lesa humanidad, los crímenes de guerra y el crimen de agresión. El mismo artículo deja en suspenso la jurisdicción sobre el crimen de agresión hasta una posterior reforma del Estatuto. Dado que esta reforma solo se aplicará respecto de los Estados que concurran a ella (art. 121(5)), es preferible omitir el crimen de agresión en el estudio de la jurisdicción de la CPI. Nos quedamos entonces con los crímenes de genocidio, de lesa humanidad y de guerra. Por regla general, la CPI solo puede ejercer su jurisdicción respecto de uno de estos delitos cuando el Estado donde se cometió, o el Estado del que el acusado es nacional, ha aceptado la jurisdicción de dicha corte. El solo hecho de ser parte del Estatuto importa aceptación de la jurisdicción de la CPI (art. 12(1)). Los Estados que no sean partes pueden aceptar la jurisdicción de la CPI especialmente (art. 12(2)). ${ }^{3}$ Aun concurriendo estos requisitos, un asunto es inadmisible ante la CPI si un Estado con jurisdicción sobre el mismo está llevando a cabo una investigación o un enjuiciamiento (litis pendentia) (art. 17(1)(a)) o ha decidido no incoar acción penal contra el imputado (art. 17(1)(b)), o si éste ya ha sido juzgado (cosa juzgada) (art. 17(1)(c)). Son estas disposiciones sobre admisibilidad las que hacen operativo el principio de complementariedad, pues tienen el efecto de otorgar preferencia al Estado para investigar y enjuiciar. Existen sin embargo excepciones que pueden interpretarse como límites a dicho principio. En efecto, la CPI puede conocer de aquellos asuntos que estén siendo investigados o enjuiciados por un Estado, o respecto de los cuales un Estado haya decidido no incoar acción penal respecto del imputado, cuando el Estado no pueda o no esté dispuesto a llevar a cabo la investigación o el enjuiciamiento. El Estatuto define lo que debe entenderse por falta de disposición ${ }^{4}$ y por incapacidad para investigar o enjuiciar. ${ }^{5}$ Asimismo, la CPI puede desconocer el efecto de cosa juzgada cuando el proceso hubiere tenido el "propósito de sustraer al acusado de su responsabilidad penal por crímenes de la competencia de la Corte" 0 "no hubiere sido instruido en forma independiente o imparcial de conformidad con las debidas garantías procesales reconocidas por el derecho

${ }^{3}$ Existe una excepción. La CPI tiene jurisdicción aun cuando ni el Estado en que se cometió el delito ni el Estado de nacionalidad del imputado hayan aceptado dicha jurisdicción, siempre que sea el Consejo de Seguridad de Naciones Unidas el que "actuando con arreglo a lo dispuesto en el Capítulo VII de la Carta de las Naciones Unidas, remit[a] al Fiscal una situación en que parezca haberse cometido uno o varios de esos crímenes[.]" (art. 13(b)). Esta excepción es irrelevante para efectos del control que ejerció el Tribunal Constitucional.

4 A fin de determinar si hay o no disposición a actuar en un asunto determinado, la Corte examinará, teniendo en cuenta los principios de un proceso con las debidas garantías reconocidos por el derecho internacional, si se da una o varias de las siguientes circunstancias, según el caso:

a) Que el juicio ya haya estado o esté en marcha o que la decisión nacional haya sido adoptada con el propósito de sustraer a la persona de que se trate de su responsabilidad penal por crímenes de la competencia de la Corte, según lo dispuesto en el artículo 5;

b) Que haya habido una demora injustificada en el juicio que, dadas las circunstancias, sea incompatible con la intención de hacer comparecer a la persona de que se trate ante la justicia;

c) Que el proceso no haya sido o no esté siendo sustanciado de manera independiente o imparcial y haya sido o esté siendo sustanciado de forma en que, dadas las circunstancias, sea incompatible con la intención de hacer comparecer a la persona de que se trate ante la justicia.

Estatuto de Roma, art. 17(2).

5 A fin de determinar la incapacidad para investigar o enjuiciar en un asunto determinado, la Corte examinará si el Estado, debido al colapso total o sustancial de su administración nacional de justicia o al hecho de que carece de ella, no puede hacer comparecer al acusado, no dispone de las pruebas y los testimonios necesarios o no está por otras razones en condiciones de llevar a cabo el juicio.

Estatuto de Roma, art. 17(3).

${ }^{6}$ Estatuto de Roma, art. 20(3)(a). 
internacional o lo hubiere sido de alguna manera que, en las circunstancias del caso, fuere incompatible con la intención de someter a la persona a la acción de la justicia."’

En las páginas que siguen se analiza las transferencias inconstitucionales de soberanía que la jurisdicción de la CPI importaría, según opinión del Tribunal Constitucional. Se revisa en primer lugar la supuesta transferencia de soberanía jurisdiccional; luego la supuesta transferencia de soberanía legislativa para conceder indultos y amnistías generales, y por último la supuesta transferencia de la soberanía del Presidente de la República para conceder indultos particulares.

\section{A. Transferencia de soberanía jurisdiccional}

La principal razón que tuvo el Tribunal para declarar la inconstitucionalidad del Estatuto de Roma fue que la atribución de jurisdicción a la CPI importaría una transferencia de soberanía vedada por la Constitución Política. Esta decisión puede ser objeto de varias críticas. En primer lugar, el Tribunal fue extremadamente confuso en la exposición del argumento, al punto que no satisface las exigencias básicas de justificación interna: no existe una conclusión que se siga lógicamente de premisas claramente establecidas. En segundo lugar, las premisas normativas se encuentran pobremente fundamentadas en el derecho vigente. Por último, el Tribunal no considera seriamente las muy problemáticas consecuencias que la universalización de dichas premisas normativas traería a diversas áreas del derecho chileno. Los tres apartados que siguen se preocupan de las dos primeras críticas. Cada uno de ellos examina una premisa normativa necesaria para alcanzar la conclusión del Tribunal y la justificación que éste ofrece para la misma. En el apartado que les sigue se analiza las consecuencias que estas premisas tendrían para el derecho chileno y las respuestas que al respecto ofreció o no ofreció el Tribunal.

La conclusión de que la atribución de jurisdicción a la CPI importa una transferencia de soberanía vedada por la Constitución Política supone tres premisas normativas. En lo que concierne a la Constitución Política supone, en primer lugar, hallar alguna norma constitucional que prohiba la transferencia de soberanía, y, en segundo lugar, vincular el concepto de soberanía con el concepto de jurisdicción. Respecto del Estatuto de Roma, la conclusión exige demostrar que éste importa transferencia de al menos una parte de la jurisdicción soberana. La mejor reconstrucción de estas premisas, conforme a la opinión del Tribunal, puede resumirse así:

1. Conforme a la Constitución Política, la soberanía reside en la nación y se ejerce por la nación y por las autoridades que la misma Constitución establece;

2. La jurisdicción territorial es un atributo esencial de la soberanía nacional, y

3. La jurisdicción de la CPI no es solo complementaria (Estatuto de Roma, preámbulo $\$ 10$ y art. 1), sino correctiva y sustitutiva de las jurisdicciones nacionales.

De las premisas segunda y tercera se sigue directamente la siguiente conclusión:

4. El Estatuto de Roma reduce la soberanía de los tribunales chilenos.

Considerada ahora la primera premisa, se concluye que:

5. El Estatuto de Roma no puede aprobarse sin previa reforma constitucional.

\footnotetext{
${ }^{7}$ Estatuto de Roma, art. 20(3)(b).
} 
En los apartados que siguen se analiza una por una las tres premisas que dan sustento a la decisión.

\section{Prohibición de transferir soberanía}

Para estimar inconstitucional la jurisdicción de la CPI no basta con afirmar que ella afecta la jurisdicción de los tribunales chilenos y que esta jurisdicción es parte de la soberanía. Aun concediendo la verdad de estas premisas -las cuales son analizadas en los dos apartados siguientes-, es necesario demostrar que la Constitución Política prohibe transferir soberanía. Se debe tener presente a estos efectos que el alcance de la prohibición puede variar. Puede tratarse tanto de una prohibición de transferir soberanía a cualquier órgano que no tenga reconocimiento constitucional, como de una prohibición de transferir soberanía a cualquier órgano que no sea parte del Estado de Chile. Aclarar cuál es el alcance de la prohibición que reconoce el Tribunal es importante, porque de ello depende que sus argumentos se extiendan o no a la transferencia de jurisdicción a tribunales chilenos que no tienen reconocimiento constitucional (infra apartado II.A.4.c). A continuación se analiza las dos versiones de la prohibición en el fallo.

a) Prohibición de transferir soberanía a órganos no constitucionales

El Tribunal fundó la norma en la disposición de la primera parte del inciso primero del artículo quinto de la Constitución Política: "La soberanía reside esencialmente en la nación. Su ejercicio se realiza por el pueblo a través del plebiscito y de elecciones periódicas y, también, por las autoridades que esta Constitución establece." En palabras del Tribunal,

Cabe destacar que el constituyente utilizó el vocablo "esta Constitución" al referirse a la posibilidad que las autoridades ejerzan soberanía de lo que se desprende con claridad que sólo éstas, además del pueblo, son las únicas que pueden ejercerla válidamente [sic]. ${ }^{8}$

Y más adelante:

[L]as únicas autoridades que pueden ejercitar soberanía son las que la Constitución establece, entre las que destaca el Presidente de la República, el Congreso Nacional y los Tribunales de la Nación. ${ }^{?}$

Es ésta una interpretación a contrario. Como tal comprende tanto a la ley como a los tratados internacionales: ninguna autoridad que no sea establecida por la Constitución puede ejercer soberanía. Aunque como toda interpretación a contrario no es invulnerable, ella es razonable atendido el sentido de la disposición. Si no se entendiera que la atribución del ejercicio de la soberanía al pueblo y a las autoridades que la Constitución establece fuera excluyente de toda otra autoridad, su sentido normativo quedaría prácticamente disuelto. En efecto, dado que aun en ausencia de la primera disposición del artículo quinto el pueblo y las autoridades que la Constitución establece podrían ejercer las atribuciones soberanas

\footnotetext{
${ }^{8}$ Considerando 37.

${ }^{9}$ Considerando 41. Más adelante, al final del considerando 51, el Tribunal repite la misma idea:

No es admisible que la ley o el Tratado, sin previa credencial constitucional, reduzca la esfera de "competencia soberana", constitucionalmente conformada, de órganos expresamente representados como "autoridades que la Constitución establece."
} 
que la misma Constitución les confía, dicha disposición solo tiene efecto útil si se le atribuye carácter excluyente.

Esta prohibición justificada a contrario encuentra algunas excepciones en reglas constitucionales especiales. Así, el artículo 73 dispone que los tribunales del Poder Judicial los establece la ley, no la Constitución. Por eso se equivoca el Tribunal cuando más adelante declara:

Que, como la función jurisdiccional es expresión del ejercicio de la soberanía, sólo la pueden cumplir las autoridades que la Constitución establece. El mandato de su artículo $5^{\circ}$, inciso primero, no admite dudas sobre el particular, sea que las autoridades jurisdiccionales a que alude se encuentren dentro ofuera del "Poder Judicial". . . . ${ }^{10}$

La regla especial del artículo 73 permite afirmar categóricamente que los tribunales del Poder Judicial se crean mediante ley, no mediante reforma constitucional. Esta regla especial no favorece sin embargo al Estatuto de Roma, puesto que la CPI no pertenece a dicho poder. Solo en este contexto cobra sentido la declaración del Tribunal Constitucional de que "la Corte Penal Internacional debiera ser uno de los tribunales exceptuados de la superintendencia de la Corte Suprema, lo que hace necesaria la adecuación de la referida disposición constitucional", la que de otro modo resulta ininteligible. ${ }^{11}$ En efecto, no es que la CPI deba exceptuarse de dicha superintendencia, sino que por tratarse de un tribunal que no pertenece al Poder Judicial, no puede favorecerse por la regla especial del artículo 73; la no sujeción a la superintendencia de la Corte Suprema es mera consecuencia de ser un tribunal internacional que por esa razón no podría ser parte del Poder Judicial chileno.

En resumen, puede ofrecerse buenas razones para justificar las siguientes proposiciones normativas:

P1: No puede establecerse autoridades para ejercer funciones soberanas sino por reforma constitucional, y

P2: Por ley puede crearse tribunales siempre que formen parte del Poder Judicial.

Esta última proposición es especial respecto de la primera.

El Tribunal fue particularmente confuso en este punto. La confusión se debe a que no articuló correctamente la relación entre su propia interpretación a contrario del artículo quinto y las disposiciones de los artículos 73 y 74 de la Constitución Política. En su considerando 44 señaló:

[N]uestra Constitución Política ... entrega su ejercicio [de la jurisdicción] en forma privativa y excluyente a los tribunales establecidos por ella o la ley, que son "las autoridades que esta Constitución establece". Así se desprende nítidamente de las disposiciones constitucionales contempladas en los artículos 73, 74, y de los Capítulos VII y VIII, que establecen al Tribunal Constitucional y a la Justicia Electoral, respectivamente.

En el pasaje citado el Tribunal hace equivalentes las expresiones 'tribunales establecidos por la Constitución o la ley' y 'autoridades que la Constitución establece'. Pero

${ }_{10}$ Considerando 45 (sin cursiva en el original).

11 Considerando 48. 
si verdaderamente fueran expresiones equivalentes, todo el argumento del Tribunal fallaría desde sus premisas. Bastaría recordar que para efectos de una reserva de ley un tratado es equivalente a una ley. Nada impediría que el Estatuto de Roma estableciera un nuevo Tribunal. En vez de identificar la expresión 'tribunales establecidos por la Constitución o la ley', que constituye una generalización apresurada de lo dispuesto en los artículos 73, 74, y de los Capítulos VII y VIII de la Constitución Política, con la expresión 'las autoridades que esta Constitución establece' usada por el artículo quinto, el Tribunal debió haber insistido en el carácter especial de la norma del artículo 73 que confía a la ley el establecimiento de los tribunales del Poder Judicial.

En resumen, y a pesar de lo ambiguo de sus considerandos, el Tribunal parece sostener que la prohibición de transferir soberanía que acarrea la inconstitucionalidad de ratificar el Estatuto de Roma sin previa reforma constitucional es la prohibición general de ejercer funciones soberanas a autoridades distintas de aquellas establecidas en la Constitución Política. Si esto es correcto, el concepto de soberanía elaborado por el Tribunal permite distribuir competencias entre el legislador y el constituyente, no solo respecto de la incorporación del derecho internacional convencional, sino también respecto de la producción del derecho doméstico: el ejercicio de cualquier facultad soberana corresponde a las autoridades que establece la Constitución, y por lo tanto solo mediante reforma constitucional se puede confiar a otras autoridades, sean domésticas, extranjeras, internacionales o supranacionales, dicho ejercicio. Esta misma idea se ve reforzada por la siguiente declaración del Tribunal:

[E]n las observaciones del Presidente de la República, se sostiene que "La jurisdicción y competencia a la C.P.I. nacen, no por transferencia de potestades propias de la soberanía nacional de los Estados Parte, sino por medio de una directa atribución que éstos efectúan, en virtud de su capacidad como sujetos de derecho internacional, mediante un acto que es propio de la soberanía externa de cada uno de ellos."...

[E]sta observación incurre en la imprecisión de dividir la soberanía, una interna y otra externa, sin considerar su esencia que es cualidad del Poder del Estado y que, en consecuencia, es única[.] ${ }^{12}$

Si esto es correcto, habría que concluir que el legislador no puede crear tribunales que no pertenezcan al Poder Judicial. Esta conclusión será analizada críticamente más abajo (apartado II.A.4.c).

b) Prohibición de transferir soberanía a órganos no estatales

Los razonamientos anteriores están en tensión con la siguiente declaración del Tribunal:

$[\mathrm{N}]$ o es dable pretender que las funciones por las que se manifiesta el Poder del Estado puedan ser renunciadas, ya sea a través de una delegación o cesión no autorizada por el Constituyente[.] ${ }^{13}$

Esta declaración solo tiene sentido en el contexto de una transferencia a órganos no estatales, pues de lo contrario no habría renuncia del poder del Estado. Si se creara un tribunal y se le confiara cierta competencia, no se estaría con ello renunciando a una

\footnotetext{
${ }^{12}$ Considerandos $54 \mathrm{~s}$
}

13 Considerando 53. 
'función por la cual se manifiesta el poder del Estado', a menos que el nuevo tribunal no fuera un órgano del Estado. Por regla general se entiende que un órgano es estatal por ejercer funciones estatales. Pero esto no es necesariamente así. Es posible sostener que para ser estatal, un órgano debe tener alguna vinculación orgánica significativa con los otros poderes del Estado. Desde este punto de vista, los órganos internacionales y supranacionales no serían estatales. Tampoco lo serían órganos domésticos de tipo comunitario. Así por ejemplo, el reconocimiento de potestad jurisdiccional a órganos comunitarios no estatales, por ejemplo de comunidades indígenas, estaría en contradicción con el principio enunciado por el Tribunal citado al comienzo de este apartado.

Desde este punto de vista el concepto de soberanía articularía una distribución de competencias entre constituyente y legislador para la transferencia o atribución de funciones estatales con base en dos criterios: (i) si las funciones confiadas son soberanas, y (ii) si el órgano al cual se confían es o no estatal. La competencia correspondería al constituyente cuando el primer criterio fuera positivo y/o el segundo criterio fuera negativo. En los demás casos, la competencia correspondería a la potestad legislativa (o, en su caso, a la potestad reglamentaria autónoma).

Esta prohibición de transferencia de soberanía presenta menos problemas que la expuesta en el apartado anterior. En particular, no acarrearía la inconstitucionalidad de tribunales como la Comisión Resolutiva Central, los directores regionales del Servicio de Impuestos Internos, los directores regionales o el Director Nacional del Servicio de Aduanas. Desgraciadamente existen muchos menos indicios de que el Tribunal prefirió ésta por sobre aquélla.

En todo caso, aún si se acepta la conclusión de que no puede crearse por ley órganos que ejerzan soberanía, excepción hecha de aquellos tribunales que pertenezcan al Poder Judicial, o bien de tribunales estatales, si se toma la segunda forma de la prohibición, resta todavía argumentar que existe un ámbito de la jurisdicción constitucionalmente reservado a los tribunales chilenos. A continuación se pasa al estudio de este punto.

\section{La soberanía jurisdiccional territorial}

Si se acepta que el inciso primero del Art. $5^{\circ}$ de la Constitución contiene una prohibición general de que mediante tratados internacionales y leyes se cree órganos que ejerzan soberanía, resulta imprescindible articular el concepto de soberanía. En el caso particular el Tribunal necesitaba establecer que la jurisdicción era un atributo de la soberanía, lo que hizo en los siguientes términos:

[E]ntre las distintas funciones públicas, entregadas por la Constitución a las autoridades que ella establece, está la función jurisdiccional que viene a ser un aspecto de cómo se ejercita la soberanía nacional[.] $]^{14}$

Y poco más adelante:

[N]uestra Constitución Política caracteriza la jurisdicción como una función pública emanada de la soberanía, lo que resulta de aplicar los artículos $5^{\circ}, 6^{\circ}$ y $7^{\circ}$ de la Constitución ... ${ }^{15}$

${ }^{14}$ Considerando 42.

15 Considerando 44. 
Aunque la referencia a esos artículos de la Constitución sea discutible en este contexto, cabe aceptar como proposición razonable que la jurisdicción es una función pública soberana. Lo difícil es determinar cómo se concreta el núcleo intransferible de jurisdicción: ¿qué es exactamente lo que no se puede transferir? ¿Cuál es la "esfera de 'competencia soberana', constitucionalmente conformada" con respecto a la jurisdicción?16 De los siguientes considerandos cabe concluir que en opinión del Tribunal esta esfera consiste en la solución de los conflictos de interés público que se promuevan dentro del territorio de la República y, en particular, de los crímenes cometidos dentro de dicho territorio:

[L]a jurisdicción . . . le corresponde ejercerla a los tribunales establecidos por la ley, lo cual confirma la aplicación del principio de la territorialidad de la jurisdicción.

Así se establece en el texto de los artículos 74 y 19, No 3 . El primero expresa

que: "Una ley orgánica constitucional determinará la organización y atribuciones de los tribunales

que fueren necesarios para la pronta y cumplida administración de justicia en todo el territorio de la República."

[T] odo conflicto en cuya solución exista un interés público comprometido queda necesariamente sometido al conocimiento y decisión de los tribunales establecidos por la ley chilena.

...

[E]l poder de un estado para ejercer jurisdicción sobre los crímenes cometidos en su territorio es un atributo esencial de la soberanía . . Sólo podrá hablarse de un Estado soberano cuando se está ante una "afirmación de poder de la supremacía dentro de un determinado territorio concretamente traducido en el ejercicio de las competencias soberanas: legislación, jurisdicción y administración" . . .17

En otras palabras, el Tribunal eleva a rango constitucional un supuesto 'principio de la territorialidad de la jurisdicción,' pero lo restringe solo a aquellos conflictos en que existe un interés público comprometido. Ésta es una conclusión grave, con insospechadas consecuencias en diversas áreas del derecho chileno, y por lo tanto debe revisarse cuidadosamente los fundamentos en que ella se sostiene.

El tribunal invoca dos tipos de autoridades: disposiciones constitucionales y afirmaciones doctrinarias. Las disposiciones constitucionales que se invoca son los artículos $5^{\circ}, 6^{\circ}, 7^{\circ}, 19 \mathrm{~N}^{\circ} 3,73$ y 74 . Ninguno de ellos permite fundar un supuesto principio de territorialidad. El Art. $5^{\circ}$ señala quién es el depositario de la soberanía (la nación), quiénes la ejercen en su nombre (el pueblo y las autoridades que la misma Constitución establece) y cuáles son sus límites (derechos fundamentales), pero no en qué consiste. El Art. $6^{\circ}$ contiene el principio de vinculación directa a la Constitución. El Art. $7^{\circ}$ establece los requisitos generales de validez de los actos estatales. El artículo $19 \mathrm{~N}^{\circ} 3$ garantiza ciertos derechos fundamentales relativos a la jurisdicción. Ninguna de estas disposiciones tiene relación alguna con un principio de la territorialidad de la jurisdicción. El artículo 73 dispone la separación del Poder Judicial, el principio de inexcusabilidad y otorga imperio a los tribunales del Poder Judicial. No establece directamente el principio de territorialidad ni vincula dicha separación, principio e imperio al territorio (aunque este último esté

${ }^{16}$ Considerando 51.

${ }_{17}$ Considerandos 49 a 51 (cursiva y subrayados en el original; se omite las referencias bibliográficas). 
territorialmente delimitado por el derecho internacional ${ }^{18}$ ). En el principio de inexcusabilidad hay una referencia a los 'negocios de . . competencia' de los tribunales, pero en ningún momento vincula esta competencia al territorio.

De las disposiciones citadas, la única que usa la palabra 'territorio' es el artículo 74. Vale la pena reproducirlo en la parte pertinente:

Una ley orgánica constitucional determinará la organización y atribuciones de los tribunales que fueren necesarios para la pronta y cumplida administración de justicia en todo el territorio de la República....

La referencia al territorio en esta disposición no tiene el alcance que pretende darle el Tribunal. Ella simplemente hace referencia al hecho de que los tribunales del Poder Judicial ejercen sus funciones en el territorio de la República. En ningún caso prejuzga cuáles sean las causas que deban conocer dichos tribunales, cuestión que ha estado tradicionalmente entregada a la ley. Aun más, esta disposición precisamente dispone una reserva de ley orgánica constitucional, pero esta reserva no está limitada por ningún supuesto principio de territorialidad. Nada impide que la ley orgánica constitucional respectiva otorgue a los tribunales jurisdicción extraterritorial. ${ }^{19}$ En resumen, el Tribunal no pudo, porque ello no es posible, encontrar fundamento en el texto constitucional al supuesto principio de la territorialidad de la jurisdicción.

Las autoridades doctrinarias son aun más débiles. El tribunal citó a su favor a Colombo, Hillier, Canotilho y Evans. Las autoridades de derecho internacional (Hillier), relaciones internacionales (Evans) y teoría constitucional (Canotilho) están fuera de lugar. No es ésta una cuestión general, sino propia del derecho constitucional chileno. De lo contrario no podría explicarse que gran número de países, algunos de ellos con fuerte tradición constitucional, no haya requerido modificar sus constituciones para ratificar el Estatuto de Roma. Tampoco podría explicarse los casos de jurisdicción extraterritorial de los tribunales chilenos. Particularmente problemática resultaría la disposición conforme a la cual:

Quedan sometidos a la jurisdicción chilena los crímenes y simples delitos perpetrados fuera del territorio de la República que a continuación se indican: . . . $6^{\circ}$ Los cometidos por chilenos contra chilenos si el culpable regresa a Chile sin haber sido juzgado por la autoridad del país en que delinquió[.] $]^{20}$

La relación de esta disposición con la jurisdicción del país en cuyo territorio se cometió el delito es análoga a la relación que existe entre la jurisdicción de la CPI y la jurisdicción de los tribunales chilenos. Si existe un principio general de territorialidad de la jurisdicción válido para todos los Estados, la citada disposición se encontraría en infracción de dicho principio.

Descartadas las soluciones generales, solo queda Colombo:

\footnotetext{
18 Corte Permanente de Justicia Internacional, El S.S. "Lotus" (Fr. v. Turq.), 1927 P.C.I.J. (ser. A) No. 10 (7 Sept., 1927).

${ }_{19}$ Esto no impide que ciertas formas de extraterritorialidad puedan ser contrarias al debido proceso. Sobre el particular, ver Rodrigo P. Correa G. "Análisis de jurisprudencia de la Corte Suprema en 2001: Derecho Internacional Público”. (Artículo en prensa)

${ }^{20}$ Código Orgánico de Tribunales, art. 6.
} 
[E]ste Tribunal Constitucional ha invocado, y lo hace una vez más, el concepto de jurisdicción en los siguientes términos: el poder-deber que tienen los tribunales para conocer y resolver, por medio del proceso y con efecto de cosa juzgada, los conflictos de intereses de relevancia jurídica que se promuevan en el orden temporal, dentro del territorio de la República y en cuya solución les corresponda intervenir (Colombo Campbell, Juan, “La Jurisdicción en el Derecho Chileno”, Ed. Jurídica de Chile, 1991, pág. 41)[.] $]^{21}$

Es ésta una buena definición, pero es ilegítimo extraer de ella consecuencias constitucionales. ¿Qué significa que un conflicto se 'promueva' dentro del territorio de la República? Son dos al menos las posibles interpretaciones: (1) que el conflicto 'surja' u 'ocurra' dentro del territorio de la República, o (2) que la acción sea interpuesta en tribunales que ejerzan funciones dentro del mismo territorio. El supuesto principio de la territorialidad de la jurisdicción corresponde a la primera interpretación. De otro modo no se entendería la afirmación del Tribunal en el sentido de que "el poder de un estado para ejercer jurisdicción sobre los crímenes cometidos en su territorio es un atributo esencial de la soberanía . .."22 Lo relevante, desde el punto de vista del Tribunal, es el lugar de comisión del delito. Si ese lugar se encuentra dentro del territorio chileno, la jurisdicción para resolverlo pertenecería a la "esfera de 'competencia soberana', constitucionalmente conformada[.]" 23 Pero si esto es así, lo que gana la definición de Colombo como norma constitucional lo pierde como definición conceptual. En efecto, habría que entender que el conocimiento de una acción interpuesta en tribunales chilenos en relación con un conflicto ocurrido fuera del territorio nacional no estaría comprendido dentro de la jurisdicción. La interpretación correcta de la definición de Colombo es que la referencia al territorio de la República dice relación con el lugar en que la acción se interpone. La idea de que existe un ámbito de asuntos cuya resolución corresponde a los tribunales chilenos no se recoge en la idea de territorio, sino en la frase 'en cuya solución les corresponda intervenir.' Pero cuáles sean los conflictos en cuya solución corresponda intervenir a los tribunales chilenos no es algo que venga determinado por la definición o concepto de jurisdicción. Es la ley la que lo determina.

Esta misma idea se confirma cuando se mira el otro elemento definitorio de los conflictos jurisdiccionales en la definición de Colombo: su promoción en el orden temporal. Este elemento de la definición tiene por objeto distinguir la jurisdicción estatal de la jurisdicción canónica. En rigor, la definición de Colombo no permite llamar a esta última jurisdicción. En este sentido la definición tiene valor pedagógico, pero no puede pretenderse que lo temporal o lo espiritual exista independientemente de su definición legislativa. Hasta antes de dictarse la ley de matrimonio civil las causas matrimoniales eran espirituales; desde entonces son temporales. La definición de Colombo no puede erigirse como un criterio constitucional auto suficiente de las causas que la ley puede o no puede confiar a los tribunales de justicia.

En conclusión, el Tribunal fracasa en su esfuerzo por encontrar fundamento constitucional a la idea de que existe un principio la territorialidad de la jurisdicción. Pero

${ }^{21}$ Considerando 43.

22 Considerando 51 (sin cursiva en el original).

${ }_{23}$ Considerando 51. 
aun concediendo que tal principio existe, el Tribunal no podía concluir que el Estatuto de Roma es inconstitucional sin antes demostrar que la jurisdicción de la CPI priva a los tribunales chilenos de alguna parte de su jurisdicción reservada. Al análisis de este punto está dedicado el siguiente apartado.

\section{Excepciones al principio de complementariedad en el Estatuto de Roma}

El Tribunal falló que:

[L]a esfera jurisdiccional que le es atribuida [a la CPI] verá reducir, correlativamente, la dimensión de soberanía constitucional deferida a los tribunales. Con el Estatuto [de Roma], la competencia soberana que es una jurisdicción constituida resultará necesariamente disminuida, por la transferencia para el Tribunal de una de sus atribuciones.

Los argumentos que llevaron al Tribunal a esta conclusión son los siguientes:

Del análisis de diversas normas del Estatuto aparece . . . que la naturaleza jurídica de la jurisdicción que ejerce la Corte Penal Internacional es de carácter correctiva y sustitutiva o supletoria, en determinados casos, de las jurisdicciones nacionales;

[D]e un estudio de lo sustantivo o esencial de las disposiciones del Estatuto . . . resulta evidente que la Corte puede corregir lo resuelto por los tribunales nacionales de los Estados Partes, pudiendo, en consecuencia, decidir en contra de lo obrado por ellos $\mathrm{y}$, en determinadas situaciones, de ausencia real o formal de dichos tribunales nacionales, sustituirlos. ${ }^{24}$

Luego de transcribir el artículo 17(1)(a)(b)(c), (2) y (3), el Tribunal concluye: es evidente que por el artículo 17, párrafo 1, a), b) y c), y párrafos 2 , a), b) y c), la Corte Penal Internacional puede corregir lo resuelto por los tribunales nacionales y, además, por el mismo artículo, párrafo 3, puede sustituir supletoriamente la jurisdicción nacional, en los casos que en dicho precepto se expresan. ${ }^{25}$

En opinión del Tribunal esta conclusión es evidente. Basta con reproducir el artículo 17 del Estatuto de Roma para justificarla. El Tribunal no debiera frustrar la voluntad de los órganos democráticos con el argumento de que dicha voluntad es evidentemente inconstitucional. En una república democrática, el Tribunal tiene la carga de la argumentación al declarar una inconstitucionalidad. En el caso particular, el artículo 17 autoriza a la CPI a conocer de un caso desconociendo los efectos de las siguientes decisiones o acciones de órganos domésticos:

a) La investigación criminal en curso;

b) El enjuiciamiento criminal en curso (litis pendentia);

\footnotetext{
${ }^{24}$ Considerandos 23 y 24 . La misma idea se reitera en el considerando 29:

[D]e las normas citadas y de lo considerado precedentemente, se concluye que la jurisdicción de la Corte que se crea, no necesariamente complementa a aquella de los tribunales de los Estados Partes, sino que, por el contrario, puede en ciertos casos, previstos expresamente por el Estatuto, llegar a revisar resoluciones ejecutoriadas dictadas por tribunales nacionales de los Estados y sustituirlas[.]

25 Considerando 25.
} 
c) La decisión de no ejercer la acción penal contra el imputado;

d) La absolución del acusado (cosa juzgada), y

e) La condena del acusado (cosa juzgada).

En Chile, desde la reforma constitucional que creó el Ministerio Público, ni la investigación criminal ni la decisión de no ejercer la acción penal tienen carácter jurisdiccional (art. 80A). En consecuencia, toda la argumentación del Tribunal relativa a la soberanía jurisdiccional falla en lo que respecta a la primera hipótesis del artículo 17(1)(a) y a la hipótesis del artículo 17(1)(b) del Estatuto. ${ }^{26}$ Solo queda la segunda hipótesis del artículo 17(1)(a), litis pendentia, y la del subpárrafo (1)(b) del mismo artículo, cosa juzgada. El Tribunal no dio importancia alguna a las condiciones que autorizan a la CPI a conocer de causas criminales en desconocimiento de la litis pendentia y la cosa juzgada. Estas condiciones son diferentes en uno y otro caso.

a) Litis pendentia

Para que la CPI pueda ignorar la defensa de litis pendentia $a_{s}$ es necesario que concurra una de las siguientes hipótesis:

(a) Que el juicio ... esté en marcha ... con el propósito de sustraer a la persona de que se trate de su responsabilidad penal por crímenes de la competencia de la CPI ...

(b) Que haya habido una demora injustificada en el juicio que, dadas las circunstancias, sea incompatible con la intención de hacer comparecer a la persona de que se trate ante la justicia;

(c) Que el proceso no ... esté siendo sustanciado de manera independiente o imparcial y ... esté siendo sustanciado de forma en que, dadas las circunstancias, sea incompatible con la intención de hacer comparecer a la persona de que se trate ante la justicia. ${ }^{27}$

Estas hipótesis deben ser evaluadas conforme a los "principios de un proceso con las debidas garantías reconocidos por el derecho internacional" ("principles of due process recognized by international law'). ${ }^{28}$ La litis pendentia también puede ser ignorada por la CPI cuando:

el Estado, debido al colapso total o sustancial de su administración nacional de justicia o al hecho de que carece de ella, no puede hacer comparecer al acusado, no dispone de las pruebas y los testimonios necesarios o no está por otras razones en condiciones de llevar a cabo el juicio. ${ }^{29}$

Supuesto que existiera una reserva constitucional de jurisdicción respecto de los delitos cometidos en Chile, ¿de qué modo dicha reserva sería infringida por estas

26 El Tribunal podría, aunque no lo hizo, haber intentado construir una esfera de competencias constitucionalmente reservadas al Ministerio Público. No se analiza aquí los méritos de esta hipótesis, pero el análisis que sigue le sería en buena medida aplicable.

27 Subpárrafos (a), (b) y (c) del artículo 17(2).

${ }^{28}$ Estatuto de Roma, art. 17(2).

${ }^{29}$ Estatuto de Roma, art. 17(3). 
disposiciones? En lo que respecta a la primera de ellas, resulta prácticamente imposible fundamentar tal infracción. El propósito de las autoridades estatales de sustraer a una persona de su responsabilidad penal es ilegítimo, salvo cuando es el propósito del legislador expresado a través de una ley de amnistía o de indulto general, o cuando es el propósito del Presidente de la República expresado a través de un decreto de indulto conforme a la ley. Estos casos quedan al margen de la litis pendentia y se estudian más adelante. Cuando el propósito ilegítimo se expresa en un enjuiciamiento, esto es, un enjuiciamiento con el propósito de sustraer al imputado de su responsabilidad penal, puede decirse que existe fraude procesal. Es al menos sostenible que en tal caso el proceso es nulo. No puede pretender el Tribunal Constitucional que dentro de la esfera constitucionalmente protegida de jurisdicción se encuentra la potestad para enjuiciar con el mencionado propósito. Desgraciadamente el Tribunal no llegó a examinar este problema.

La segunda hipótesis puede ser más controvertida. El derecho a una justicia pronta ha sido reconocido, por ejemplo, en el Pacto Internacional de Derechos Civiles y Políticos:

Durante el proceso, toda persona acusada de un delito tendrá derecho, en plena igualdad, a las siguientes garantías mínimas:

...

b) A ser juzgado sin dilaciones indebidas[.] ${ }^{30}$

Cabe sostener que en una interpretación garantista de la Constitución, la jurisdicción no es compatible con una duración excesiva del juicio. También se puede sostener que este derecho forma parte del derecho más amplio a un justo y racional procedimiento, que reconoce el artículo $19 \mathrm{~N}^{\mathrm{o}} 3$ de la Constitución Política. No resulta entonces razonable sostener que la demora en los juicios forma parte esencial de la jurisdicción. Por otra parte, esta interpretación garantista de la jurisdicción tiene sus justos límites en ese mismo garantismo. Esto obligaría a distinguir entre dos tipos de dilaciones: aquellas a favor y aquellas en contra del imputado o acusado. En rigor, el citado derecho a un derecho a ser juzgado sin dilaciones indebidas, como asimismo el derecho a un justo y racional procedimiento, solo excluyen la legitimidad de aquellas dilaciones en contra del imputado o acusado. No tiene sentido sostener que el acusado tiene derecho a un proceso sin dilaciones cuando dichas dilaciones son a su favor. Tampoco es razonable interpretar este derecho con prescindencia de los recursos materiales y humanos disponibles en un determinado Estado. En la medida en que la duración de los procesos es función de dichos recursos, y que éstos son escasos y deben ser asignados a innumerables necesidades, el grado de exigibilidad del derecho debe ser ponderado. En consecuencia, no pareciera que la demora excesiva tenga per se una antijuridicidad semejante a la del propósito de sustraer a un imputado de su responsabilidad penal expresada a través de un juicio simulado. Si la duración excesiva de un proceso fuera suficiente para autorizar a la CPI a desconocer la litis pendentia, podría haber una disminución de la autonomía estatal para la asignación de recursos que mereciera un escrutinio estricto. No es sin embargo la demora excesiva una condición suficiente. Debe tratarse de una demora "injustificada" e "incompatible con la intención de hacer comparecer a la persona de que se trate ante la justicia." Estas calificaciones se exigen copulativamente. Ellas parecen salvar los problemas del artículo

30 Pacto de Derechos Civiles y Políticos, art. 14(3)(c); San José de Costa Rica; adopción, 16 de diciembre de 1966; entrada en vigor, 23 de marzo de 1976; ratificación, 10 de febrero de 1972; Decreto 778 de 30 de noviembre de 1976; D.O. de 29 de abril de 1989. 
17(2)(b), a menos que el Tribunal Constitucional esté dispuesto a sostener que forma parte de la esfera constitucionalmente reservada a los tribunales la potestad de demorar injustificadamente un juicio de modo tal que sea incompatible con la intención de hacer comparecer a la persona de que se trate ante la justicia.

La tercera hipótesis exige dos requisitos copulativos. Primero, falta de independencia o imparcialidad; segundo, sustanciación del juicio de forma incompatible con la intención de hacer comparecer a la persona de que se trate ante la justicia. Valen aquí consideraciones similares a las hechas a propósito de las dos hipótesis precedentes. Si la hipótesis bajo examen tiene por efecto reducir la soberanía jurisdiccional nacional, ello ha de ser porque la potestad para conducir un juicio sin las garantías de imparcialidad o independencia forma parte de la jurisdicción. Ésta es una conclusión inaceptable.

Resta analizar la última hipótesis. Ésta exige la procedencia de uno de tres requisitos (colapso total, colapso sustancial o ausencia de la administración nacional de justicia) que debe dar lugar a uno de dos problemas específicos (el Estado no puede hacer comparecer al acusado o no dispone de pruebas y testimonios) o algún otro problema que impida al Estado llevar a cabo el juicio. En relación con esta hipótesis simplemente carece de sentido pensar en una reserva constitucional de la jurisdicción, pues se trata de casos en los que el orden constitucional está en crisis y las condiciones para ejercer la jurisdicción no existen. ${ }^{31}$

c) Cosa juzgada

Los casos en que la CPI puede desconocer la excepción de cosa juzgada se encuentran en el artículo 20(3) del Estatuto. Se trata de casos en que el proceso en el que se haya dictado la sentencia cuyos efectos precluyentes son pasados por alto:

a) Obedeciera al propósito de sustraer al acusado de su responsabilidad penal por crímenes de la competencia de la CPI; o

b) No hubiere sido instruido en forma independiente o imparcial de conformidad con las debidas garantías procesales reconocidas por el derecho internacional o lo hubiere sido de alguna manera que, en las circunstancias del caso, fuere incompatible con la intención de someter a la persona a la acción de la justicia.

Por las mismas razones expuestas a propósito de las hipótesis aplicables a la litis pendentia, resulta muy difícil sostener que con estas disposiciones se infringe la soberanía jurisdiccional nacional. Ello supondría incluir en el concepto de jurisdicción la legitimidad del propósito de sustraer a una persona de su responsabilidad penal o de la falta de independencia o imparcialidad. Esto no es sostenible. Desgraciadamente el Tribunal no examinó el problema desde una perspectiva garantista. Es posible que las disposiciones del artículo 20(3) del Estatuto de Roma, al menos en ciertos casos, sean contrarias a ciertas restricciones al ejercicio del ius puniendi que descansan en derechos fundamentales.

31 En el mismo sentido, Francia, Conseil Constitutionnel, decisión No 98-408 DC (1999), disponible en http://www.conseil-constitutionnel.fr/decision/ 1998/98408/index.htm. 
Como cualquier disposición jurídica, las causales de admisibilidad en situaciones de litis pendentia y de cosa juzgada pueden ser abusadas. Ésta parece haber sido una preocupación especial del Tribunal, según se desprende de los siguientes considerandos: [D]ebe precisarse, también, que conforme al articulo 19, párrafo 1, y artículo 57, párrafo 2, letra a), del Tratado, quién resuelve sobre admisibilidad de la jurisdicción de la Corte es la Sala de Cuestiones preliminares, de conformidad con las normas del Estatuto; [L]o anterior, es sin perjuicio de la apelación que puede deducirse ante la Sala de Apelación de la misma Corte, de acuerdo a los artículos 19 y 82, párrafo 1, letra a); $[D]$ e un examen exhaustivo del Estatuto de la Corte Penal Internacional, es evidente que es la propia Corte la que resuelve sobre su competencia para conocer de las materias entregadas a su conocimiento[.] $]^{32}$

Es correcto que es la propia CPI la que decide sobre la admisibilidad de los casos. También es cierto que esta potestad puede ser abusada. Por último, también es cierto que tal abuso puede, en los hechos, convertir a las causales analizadas en letra muerta y reemplazarlas por otras que efectivamente tengan por efecto reducir los ámbitos ordinarios de ejercicio de las jurisdicciones nacionales. Pero ninguna de éstas es razón para declarar inconstitucional el Estatuto de Roma. El que una disposición pueda ser abusada debe ser objeto de ponderación política, no constitucional. Corresponde al Presidente de la República y al Congreso Nacional evaluar si el riesgo de abuso es tan alto que exponga la autonomía del Estado en un nivel inaceptable. Pero no puede el Tribunal Constitucional pasar por alto la cuidadosa redacción de las causales de admisibilidad solo porque es la propia CPI la que las califica. ${ }^{33}$

e) Obligación de investigar y juzgar a que está sujeto Chile de conformidad con el derecho internacional

Al declarar que la jurisdicción de la CPI es correctiva o sustitutiva de las jurisdicciones nacionales sin examinar las causales de admisibilidad de los artículos $17 \mathrm{y}$ 20(3) del Estatuto de Roma, el Tribunal Constitucional demostró un total desprecio por las obligaciones a que está sujeto Chile bajo el derecho internacional. El extremo opuesto se encuentra en la decisión del Conseil Constitutionnel francés, ignorada por el Tribunal Constitucional en este punto, la que analizando el mismo punto llegó a la siguiente conclusión:

Cuando el Estado se ha sometido voluntariamente a las obligaciones nacidas de la Convención, aquellas disposiciones del tratado que importan restricciones al principio de complementariedad de la Corte en relación con las jurisdicciones penales nacionales, derivan de la regla pacta sunt servanda, en aplicación de la cual todo tratado en vigor obliga a las partes y debe ser cumplido por ellas de buena fe [y que] dichas disposiciones fijan taxativa y objetivamente las hipótesis bajo las cuales la Corte Penal Internacional podrá declararse competente[.] $]^{34}$

\footnotetext{
32 Considerandos 26 a 28.

33 Tribunal Federal Aleman: Maastricht.

${ }^{34}$ Conseil Constitutionnel, decisión No 98-408 DC (1999), cit.
} 
La virtud del enfoque del Conseil es que precisamente hace lo que no hizo el Tribunal Constitucional: vincula las causales de admisibilidad a obligaciones a que está sujeto el Estado francés en virtud del Estatuto. Estas obligaciones no pueden ser otras que la obligación de investigar y juzgar los crímenes bajo la jurisdicción de la CPI, a saber, el genocidio, los crímenes contra la humanidad y los crímenes de guerra. Pero esta virtud del enfoque francés va acompañada del vicio de dar por hecho que tal obligación existe, sin proceder a un examen cuidadoso del texto del Estatuto.

Diversas pueden ser las fuentes de la obligación de juzgar los crímenes de jurisdicción de la CPI: el propio Estatuto, otros tratados internacionales, el derecho internacional consuetudinario, o los principios generales del derecho internacional. La implicación del Conseil de que esa obligación se encuentra en el Estatuto es derechamente incorrecta. El Estatuto no establece obligación alguna de investigar o juzgar. Según se explicó más arriba, ofrece más bien la oportunidad de investigar y juzgar a los Estados con jurisdicción sobre los asuntos de que se trate. El Estado que no haga uso de esta oportunidad no viola por ello disposición alguna del Estatuto. Lo dicho no debe confundirse con el hecho de que el artículo 89(1) del Estatuto imponga a los Estados partes la obligación de cumplir las solicitudes de detención y entrega de determinadas personas que le formule la CPI. Ésta es una obligación de cooperación con la CPI, procedente cuando un caso ya ha sido declarado admisible. No se trata de una obligación cuyo incumplimiento sea condición de admisibilidad. Sin embargo, el hecho de que el Conseil haya errado en este punto no quita que su enfoque sea mejor que el del Tribunal Constitucional. Si el Estado estuviera obligado a investigar y juzgar en virtud de otras fuentes del derecho internacional, sería correcta la conclusión de que la jurisdicción de la CPI no podría ser inconstitucional solo en razón de que concurre con la jurisdicción de los tribunales chilenos, a menos que la obligación de investigar y juzgar fuera ella misma inconstitucional. En otras palabras, el examen de constitucionalidad de la jurisdicción de la CPI demandaba un examen de las obligaciones a que está sujeto el Estado de Chile de investigar y juzgar los crímenes de genocidio, crímenes contra la humanidad y crímenes de guerra.

El análisis pormenorizado de tales obligaciones queda para otra oportunidad. Baste ahora señalar que respecto de algunos delitos bajo la jurisdicción de la CPI es indudable que Chile tiene la obligación de investigar y juzgar. A modo de ejemplo puede citarse los artículos primero y sexto de la Convención contra el Genocidio:

Artículo I

Las Partes contratantes confirman que el genocidio, ya sea cometido en tiempo de paz o en tiempo de guerra, es un delito de derecho internacional que ellas se comprometen a prevenir y a sancionar.

Artículo VI

Las personas acusadas de genocidio o de uno cualquiera de los actos enumerados en el artículo III, serán juzgadas por un tribunal competente del Estado en cuyo territorio el acto fue cometido, $o$ ante la corte penal internacional que sea 
competente respecto a aquellas de las Partes contratantes que hayan reconocido su jurisdicción. ${ }^{35}$

Similares disposiciones se encuentran en las convenios de Ginebra sobre derecho de la guerra y sus protocolos adicionales (al menos el primero). Estas convenciones establecen reglas de conducta para situaciones de conflicto armado, definen lo que debe entederse por una infracción grave contra dichas reglas, e imponen la obligación a los Estados partes de incriminar, investigar y juzgar dichas infracción. Así por ejemplo, los dos primeros incisos del Art. 49 del Convenio de Ginebra para Aliviar la Suerte que Corren los Heridos y los Enfermos de las Fuerzas Armadas en Campaña disponen:

Las Altas Partes Contratantes se comprometen a tomar todas las oportunas medidas legislativas para determinar las adecuadas sanciones penales que se han de aplicar a las personas que hayan cometido, o dado orden de cometer, una cualquiera de las infracciones graves contra el presente Convenio definidas en el artículo siguiente. Cada una de las Partes Contratantes tendrá la obligación de buscar a las personas acusadas de haber cometido, u ordenado cometer, una cualquiera de las infracciones graves, y deberá hacerlas comparecer ante los propios tribunales, sea cual fuere su nacionalidad. Podrá también, si lo prefiere, y según las disposiciones previstas en la propia legislación, entregarlas para que sean juzgadas por otra Parte Contratante interesada, si ésta ha formulado contra ellas cargos suficientes. ${ }^{36}$

El deber de punición de las infracciones graves al derecho de ginebra cubre muchos de los supuestos de hecho constitutivos de crímenes de guerra, previstos en el Art. 8 del Estatuto de Roma. Respecto de estos crímenes y del crimen de genocidio (Art. 6 del Estatuto de Roma), por consiguiente, es plenamente aplicable el argumento del Conseil. En el extremo opuesto se encuentra el delito del artículo 7(1)(k) del Estatuto de Roma:

Otros actos inhumanos de carácter similar que causen intencionalmente grandes sufrimientos o atenten gravemente contra la integridad física o la salud mental o física.

No existe tratado alguno que imponga al Estado la obligación de sancionar este delito. Aunque existiera, su constitucionalidad sería dudosa, pues la descripción típica no satisface las exigencias del principio de legalidad. Frente a este hecho, muchos internacionalistas alegan que la obligación de investigar y juzgar estos delitos encuentra su fuente en el derecho internacional consuetudinario, y que por tal motivo la falta tanto de un

35 Convención para la Prevención y la Sanción del Delito de Genocidio; adopción, 9 de diciembre de 1948; entrada en vigor, 12 de enero de 1951, ratificación, 3 de junio de 1953; Decreto 316 de 5 de junio de 1953; D.O. de 11 de diciembre de 1953.

${ }^{36}$ Convenio de Ginebra para Aliviar la Suerte que Corren los Heridos y los Enfermos de las Fuerzas Armadas en Campaña, 12 de agosto de 1949, ratificación, 12 de octubre de 1950; Decreto 752 de 5 de diciembre de 1950, D.O. de 17 de abril de 1951. Del mismo tenor, Convenio de Ginebra para Aliviar la Suerte que Corren los Heridos, los Enfermos y los Náufragos de las Fuerzas Armadas en el Mar, del 12 de Agosto de 1949, ratificación, 12 de octubre de 1950, Decreto 752 de 5 de diciembre de 1950, D.O. de 18 de abril de 1951, art. 50; Convenio de Ginebra relativo al Trato Debido a los Prisioneros de Guerra, del 12 de Agosto de 1949, ratificación, 12 de octubre de 1950, Decreto 752 de 5 de diciembre de 1950, D.O. de 19 de abril de 1951, art. 129; Convenio de Ginebra relativo a la Protección Debida a las Personas Civiles en Tiempo de Guerra, 12 de agosto de 1949, ratificación, 12 de octubre de 1950, Decreto 752 de 5 de diciembre de 1950, D.O. de 20 de abril de 1951, art. 146; Protocolo Adicional a los Convenios de Ginebra del 12 de agosto de 1949 relativo a la Protección de las Víctimas de los Conflictos Armados Internacionales, 8 de junio de 1977, ratificación, 24 de abril de 1991, Decreto 752 de 17 de junio de 1991, D.O. de 28 de octubre de 1991, art. 85. 
deber de juzgar como de una descripción típica en un tratado internacional es irrelevante. Esta tesis enfrenta sin embargo un problema considerable: la práctica de los Estados tiende a desmentir la existencia de normas consuetudinarias en tal sentido. Buena parte de los países que han salido de un período de significativas violaciones a los derechos humanos ha optado por algún grado de solución distinto de la investigación y enjuiciamiento. Frente a esta realidad, algunos internacionalistas han optado por fundar tales normas directamente en principios generales vinculados al derecho internacional de los derechos humanos. ${ }^{37}$ Resulta sin embargo dudoso que estos principios puedan prestar esa función, pues del reconocimiento de un derecho no se sigue sin más un mandato de punición de los actos u omisiones que lo lesionen. 38

\section{Consecuencias del fallo jurisdiccional}

Conforme a lo expuesto, la decisión jurisdiccional del Tribunal Constitucional es deficiente porque (1) no estableció con claridad cuál es la prohibición de trasferencia de soberanía que aplicó, (2) elevó a rango constitucional el principio de la territorialidad de la jurisdicción sin fundamentos plausibles, (3) invirtió la carga de la argumentación al declarar que la jurisdicción de la CPI es sustitutiva o correctiva de la jurisdicción nacional y (4) confundió factores de ponderación política con cuestiones de constitucionalidad. Estos errores del tribunal constitucional tienen consecuencias importantes para otras áreas del derecho chileno. En particular, serían inconstitucionales:

a) las disposiciones de tratados internacionales vigentes mediante las cuales Chile reconoce la jurisdicción de tribunales no chilenos para conocer y juzgar causas criminales que tengan su origen en el territorio nacional;

b) las disposiciones de tratados internacionales vigentes y de leyes que autorizan a las partes de un conflicto civil a someterlo a la decisión de tribunales no chilenos o de árbitros, y

c) todos los tribunales chilenos que ejercen jurisdicción no obstante no estar reconocidos por la Constitución Política ni pertenecer al Poder Judicial (Comisión Resolutiva Central, directores regionales del Servicio de Impuestos Internos, directores regionales del Servicio de Aduanas).

El Tribunal no parece haber reparado en el alcance que sus razonamientos tienen respecto del último problema mencionado. No puede decirse lo mismo respecto de los problemas primero y segundo, que de algún modo fueron explícitamente discutidos por el Tribunal, aunque los argumentos ofrecidos no sean suficientes para evitar el resultado no deseado. El hecho de que una declaración de inconstitucionalidad cree incertidumbre sobre la constitucionalidad de disposiciones jurídicas distintas de aquellas que son objeto de control no es por sí solo razón para no declarar dicha inconstitucionalidad. Pero sí es razón para elevar la carga de argumentación del Tribunal. De lo contrario sufre la propia autoridad del Tribunal, pues los efectos negativos que se seguirían de sus fallos si fueran tomados en serio obligan a no tomarlos en serio. Esta mayor carga argumentativa viene

\footnotetext{
${ }^{37}$ Para una crítica a estas formas de argumentación, ver Antonio Bascuñán Rodríguez, op. cit., supra, nota 2.

38 Sobre los problemas de probar la existencia de tal obligación consuetudinaria, ver Kai Ambos, Impunidady Derecho Penal Internacional (Buenos Aires: Ad-Hoc 1999), Michael Scharf, “The Letter of the Law: The Scope of the International Legal Obligation to Prosecute Human Rights Crimes”, 59 Law \& Contemp. Prob. 41, 52-9 (1996).
} 
asimismo demandada por el lugar que corresponde al Tribunal Constitucional en una constitución democrática: el Tribunal debe dar buenas razones para obstruir la expresión de la voluntad de los órganos representativos. ${ }^{39}$ Con esto en mente se pasa al examen de las consecuencias del fallo.

a) Reconocimiento de jurisdicciones no chilenas para conocer y juzgar delitos ocurridos en Chile

El Estado de Chile es parte de varios tratados mediante los cuales reconoce la jurisdicción de tribunales no chilenos para juzgar delitos cometidos en Chile. Tómese a modo de ejemplo el Art. $5^{\circ}$ de la Convención contra la Tortura y Otros Tratos o Penas Crueles, Inhumanos o Degradantes:

1. Todo Estado Parte dispondrá lo que sea necesario para instituir su jurisdicción sobre los delitos a que se refiere el artículo 4 en los siguientes casos:

a) Cuando los delitos se cometan en cualquier territorio bajo su jurisdicción o a bordo de una aeronave o un buque matriculados en ese Estado;

b) Cuando el presunto delincuente sea nacional de ese Estado;

c) Cuando la víctima sea nacional de ese Estado y éste lo considere apropiado.

2. Todo Estado Parte tomará asimismo las medidas necesarias para establecer su jurisdicción sobre estos delitos en los casos en que el presunto delincuente se halle en cualquier territorio bajo su jurisdicción y dicho Estado no conceda la extradición, con arreglo al artículo 8, a ninguno de los Estados previstos en el párrafo 1 del presente artículo.

3. La presente Convención no excluye ninguna jurisdicción penal ejercida de conformidad con las leyes nacionales. ${ }^{40}$

Por este artículo el Estado de Chile reconoce la jurisdicción de los siguientes Estados para juzgar actos de tortura cometidos en Chile: (a) Estado de nacionalidad del imputado; (b) Estado de nacionalidad de la víctima, y (c) Estado en cuyo territorio se hallare el imputado. Conforme a lo razonado por el Tribunal Constitucional en el fallo que se comenta, la Constitución Política reserva a los tribunales chilenos la jurisdicción de esos delitos, por el solo hecho de cometerse en Chile. En consecuencia, las disposiciones del

\footnotetext{
${ }^{39}$ El lugar que corresponde a la justicia constitucional en una república democrática es un asunto controvertido. Ver Víctor Ferreres Comella, Justicia Constitucional y Democracia (Madrid: Centro de Estudios Políticos y Constitucionales 1997). Entre nosotros, quien con mayor agudeza ha cuestionado el rol de la justicia constitucional es el profesor Fernando Atria. Ver su "Legalismo, Derechos y Política," en Derechos Fundamentales (Buenos Aires: Editores del Puerto, en prensa).

40 Convención contra la Tortura y Otros Tratos o Penas Crueles, Inhumanos o Degradantes, adopción, 10 de diciembre de 1984, entrada en vigor, 26 de junio de 1987, ratificación, 30 de septiembre de 1988, Decreto 808 de 7 de octubre de 1988; D.O. de 26 de noviembre de 1988.
} 
artículo 5(1)(b)(c) y (2) serían inconstitucionales. Igual suerte correrían las disposiciones de otros muchos tratados internacionales. ${ }^{41}$

¿Es posible distinguir estos reconocimientos de jurisdicciones no chilenas del reconocimiento de jurisdicción de la CPI hecha por el TPI, de modo que la inconstitucionalidad de éste no alcance la de aquellos? El Tribunal intentó trazar una línea que permitiera hacer la distinción:

[L]a Corte Penal Internacional tiene características que permiten calificarla como un tribunal supranacional, en razón de las disposiciones del Estatuto transcritas anteriormente en este fallo aparece en forma indubitable la diferencia entre ambos tipos de tribunales [sic].

La Corte Penal Internacional se distingue por ser un tribunal "permanente" que ejerce su jurisdicción sobre personas naturales y, en ciertos casos, por sobre las jurisdicciones penales nacionales a que se encuentran sometidas esas personas que sean procesadas por los delitos que contempla el Estatuto de la Corte;

[L]os tribunales internacionales establecidos en tratados ratificados por Chile, como por ejemplo, la Convención Americana sobre Derechos Humanos, de San José de Costa Rica, y el Estatuto de la Corte Internacional de Justicia de la Haya, no tienen una supervigilancia correctiva o sustitutiva de las resoluciones de los tribunales nacionales.

Como bien dice la profesora Angela Vivanco en el Informe en Derecho y exposición ante la Cámara de Diputados y sustentándose fundamentalmente en el artículo 17 del Estatuto, antes transcrito:

“a) La presunta idea de la acción de la Corte como complementaria a la de los tribunales chilenos se pierde del todo, ya que se superpone totalmente a la actividad de éstos, y aún más, el juzgamiento que ellos puedan hacer previamente de un asunto, no tendrá más mérito que el que en criterio de la Corte éste tenga.

b) De esta forma, la Corte se transforma en una instancia de supervigilancia respecto de los tribunales de justicia chilenos, incluida la Corte Suprema, ya que tiene la facultad de examinar sus intenciones y motivaciones al juzgar, cosa que le está expresamente prohibida de hacer tanto al Presidente de la República como al Congreso Nacional de acuerdo al artículo 73 de la Carta. De esta forma, en materia, la Corte será más soberana que la totalidad de los poderes públicos del país." ${ }^{42}$

El Tribunal distingue entonces entre tribunales supranacionales y tribunales internacionales. Solo los primeros serían problemáticos desde el punto de vista constitucional. La CPI sería un tribunal supranacional. Otras jurisdicciones reconocidas por Chile serían internacionales. Cabe preguntarse cuál es el criterio que permite hacer la distinción. El pasaje transcrito no es particularmente claro al respecto, pero permite sostener que dicho criterio es uno de los siguientes:

41 Convención Internacional contra la Toma de Rehenes, art. 5; adoptada, 17 de diciembre de 1979; entrada en vigor, 3 de junio de 1983, ratificación, 12 de noviembre de 1981, Decreto 989 de 16 de noviembre de 1981, D.O. de 8 de enero de 1982; Convención para la Represión del Apoderamiento Ilícito de Aeronaves, art. 7, adoptada, La Haya, 16 de diciembre de 1970, entrada en vigor, 14 de octubre de 1971, ratificación, 2 de febrero de 1972, Decreto 147 de 20 de marzo de 1972, D.O. de 19 de abril de 1972.

${ }^{42}$ Considerandos 32 y 33. 
a) el carácter permanente o ad hoc del tribunal;

b) la calidad de las personas sobre las que se ejerce jurisdicción (naturales vs. ¿Estados?);

c) el que la jurisdicción del tribunal en cuestión se ejerza o no por sobre las jurisdicciones penales nacionales, $y$

d) el que el tribunal en cuestión tenga o no supervigilancia correctiva o sustitutiva de las resoluciones de los tribunales nacionales.

El primero de estos criterios es a todas luces irrelevante para hacer la distinción. Desde luego, el propio Tribunal en el pasaje transcrito intenta distinguir a la CPI de la Corte Interamericana de Derechos Humanos y de la Corte Internacional de Justicia, tribunales ambos permanentes. El segundo criterio es problemático. Tanto las personas como el Estado están sujetos a la jurisdicción chilena. ¿Por qué habría de ser cualitativamente diferente la afectación de la soberanía jurisdiccional en uno y otro caso? De hecho, el criterio es fuertemente contra intuitivo. El ámbito de soberanía jurisdiccional del país parece fuertemente afectado cuando la Corte Interamericana de Derechos Humanos falla que una resolución de los tribunales chilenos importa infracción de la Convención Interamericana de Derechos Humanos. ${ }^{43}$ Quedan entonces los dos últimos criterios. Sin embargo, ellos también fracasan. Lo que parece haber determinado la declaración de inconstitucionalidad del Estatuto de Roma es el hecho de que la CPI pueda, bajo ciertas condiciones, ignorar los efectos de la litis pendentia y la cosa juzgada. La inconstitucionalidad no se encontraría entonces en la atribución de jurisdicción a la CPI o a tribunales distintos de los chilenos para conocer y juzgar delitos ocurridos en Chile, sino más específicamente en atribuir a esos tribunales la facultad para pasar por sobre los efectos naturales de las resoluciones de tribunales chilenos. Es ésa la idea que recogen los dos últimos criterios. Pues bien, nada hay en el artículo quinto de la Convención contra la Tortura, ni en disposiciones análogas de otros tratados internacionales, que explícitamente reconozca a jurisdicciones no chilenas la potestad para desconocer la litis pendentia o la cosa juzgada respecto de procesos o sentencias chilenos. Mientras los tribunales no chilenos reconocieran dichos efectos, no sería inconstitucional atribuirles jurisdicción. Esta distinción entre el reconocimiento de la jurisdicción de la CPI y los reconocimientos de jurisdicción de diversos tribunales no chilenos para conocer de delitos cometidos en Chile es en principio razonable. Sin embargo, un examen más cuidadoso demuestra que ella enfrenta problemas considerables. No es legítimo sostener sin más que el silencio respecto de la litis pendentia y de la cosa juzgada importa que dichos efectos serán respetados tratándose de procesos o sentencias del Estado en cuyo territorio se cometieron los delitos. Por el contrario, el asunto Pinochet en España e Inglaterra tiende a demostrar que las jurisdicciones extranjeras pueden sentirse con completa libertad para ignorarlos. ${ }^{44}$ Además, debe recordarse que el Estatuto de Roma explícitamente reconoce que la litis pendentia y la cosa juzgada acarrean la inadmisibilidad de un asunto ante la CPI, salvas especialísimas excepciones. En resumen, y la experiencia con el asunto Pinochet es una buena muestra de ello, las cláusulas de reconocimiento de jurisdicciones no chilenas en tratados internacionales distintos del Estatuto de Roma importan tanta o mayor restricción de la

43 Corte Interamericana de Derechos Humanos, Caso "La Última Tentación de Cristo" (Olmedo Bustos y otros), sentencia de 5 de febrero de 2001, Serie C No. 73.

44 Ver Jordan J. Paust, "It's No Defense: Nullum Crimen, International Crime and the Gingerbread Man", 60 Alb. L. Rev. 657, 662s (1997). Paust argumenta que el principio ne bis in idem solo tiene validez dentro de un mismo sistema jurídico, y que por lo tanto un Estado no está obligado a reconocer el efecto de cosa juzgada de una absolución o condena dictada por otro Estado. 
autonomía de los tribunales nacionales que el reconocimiento de la jurisdicción de la CPI.45 Es por tanto difícil sostener la inconstitucionalidad del Estatuto sin sostener a la vez la inconstitucionalidad de todos los demás reconocimientos de jurisdicciones no chilenas para juzgar delitos cometidos en Chile.

Por otra parte, el criterio ni siquiera sirve para distinguir las jurisdicciones de la Corte Interamericana de Derechos Humanos y la de la Corte Internacional de Justicia. Desde que en derecho internacional se acepta que una resolución judicial puede constituir infracción del derecho internacional, dichos tribunales tienen, si así se quiere llamar, 'supervigilancia correctiva o sustitutiva de las resoluciones de los tribunales nacionales.'

\section{b) Reconocimiento de jurisdicciones no chilenas para conocer y juggar asuntos civiles ocurridos en Chile}

El artículo 1462 del Código Civil dispone que "Hay un objeto ilícito en todo lo que contraviene al derecho público chileno. Así la promesa de someterse en Chile a una jurisdicción no reconocida por las leyes chilenas, es nula por el vicio del objeto." El alcance de esta disposición es controvertido. Pero lo que interesa ahora es aquello sobre lo que no hay controversia. Se trata de lo siguiente: sea cual sea el contenido normativo de la disposición, ella se dirige a las partes de una convención civil, no al legislador. El legislador es libre para reconocer una jurisdicción no chilena, en cuyo caso no habrá objeto ilícito en la convención que se someta a ella. Además, por tratarse de una disposición meramente legal, el legislador es libre para derogarla o para dictar normas especiales. En la práctica, tanto mediante leyes como mediante tratados internacionales se ha reconocido jurisdicciones no chilenas para conocer y juzgar asuntos civiles o se ha dictado normas especiales respecto del artículo 1462 del Código Civil. Entre las más conocidas se encuentra

45 Cámara de los Lores, Regina v Bow Street Metropolitan Stipendiary, ex parte Pinochet Ugarte (No. 3), sentencia de 24 de marzo de 1999, [2000] 1 A.C. 147, per Lord Browne-Wilkinson ("el senador Pinochet goza de inmunidad ratione materice en su calidad de ex jefe de Estado en relación con actos ejecutado por él como jefe de Estado como parte de sus funciones oficiales como jefe de Estado." "Si, como se alega, el senador Pinochet organizó y autorizó tortura después del 8 de diciembre de 1988, él no estaba actuando bajo capacidad alguna que dé lugar a inmunidad ratione materia, porque dichas acciones eran contrarias al derecho internacional, Chile había convenido declarar dichas conductas como antijurídicas y Chile había convenido con las otras partes de la Convención contra la Tortura que los estados signatarios tendrían jurisdicción para juzgar la tortura oficial (según definición de la Convención), aun si esa tortura era cometida en Chile.”); per Lord Goff of Chieveley ("un jefe de Estado gozará, tanto en virtud de la ley [inglesa] como del derecho internacional, de inmunidad ratione persona mientras se mantenga en funciones, y luego que deja su cargo gozará de inmunidad ratione materice 'respecto de actos [por é] ejecutados en ejercicio de sus funciones [como jefe de Estado]' ..." (se omite la referencia bibliográfica). Sin embargo, Lord Goff of Chieveley discrepó con Lord Browne-Wilkinson en cuanto a que la Convención contra la Tortura tendría el efecto de excluir la inmunidad ratione materice en relación con dicho delito). Lord Hope of Craighead, Lord Hutton y Lord Saville of Newdigate tuvieron una opinión similar a la de Lord Browne-Wilkinson. Lord Millett fue de la opinión que la inmunidad no cubría ningún delito cometido fuera de Chile y que la fecha de comisión de la tortura era irrelevante. Lord Phillips of Worth Matravers sostuvo que la inmunidad no cubría ningún delito extraditable. En resumen, hizo mayoría la opinión de que la Convención contra la Tortura había tenido por efecto excluir la tortura de cualquier inmunidad ratione materia. En cuanto a la inmunidad ratione persona, ver la reciente decisión de la Corte Internacional de Justicia en Case Concerning the Arrest Warrant of 11 April 2000 (Rep. Democrática del Congo v. Bélgica), sentencia de 14 de febrero de 2002. La Corte declaró que un ministro de relaciones exteriores en ejercicio goza de inmunidad de jurisdicción civil y penal bajo el derecho consuetudinario internacional (párrafos 51 a 55). La Corte rechazó el argumento del Estado belga de que dicha inmunidad no cubre acusaciones de crímenes de guerra y crímenes de lesa humanidad (párrafos 56 a 58). 
las disposiciones del Código de Bustamante y del D.L. 2.349.46 También puede señalarse el artículo II de la Convención de Nueva York, ${ }^{47}$ la Convención de Washington de 1965, ${ }^{48}$ el tratado de libre comercio con Canadá y el sinnúmero de acuerdos bilaterales para la protección y promoción de inversiones celebrados por Chile. Todos estos tratados tienen en común el reconocimiento de jurisdicciones no chilenas, tanto judiciales como arbitrales, para conocer y juzgar causas civiles comprendidas dentro de la jurisdicción de los tribunales chilenos. En general, se trata de disposiciones de gran importancia para el desarrollo del comercio internacional y la promoción de la inversión extranjera en Chile.

El fallo del Tribunal Constitucional respecto del Estatuto de Roma arroja un manto de duda sobre la constitucionalidad de estas disposiciones. El Tribunal parece haber estado consciente de este problema, y cree haberlo salvado con la siguiente declaración:

de las disposiciones invocadas, debe concluirse que todo conflicto en cuya solución exista un interés público comprometido queda necesariamente sometido al conocimiento y decisión de los tribunales establecidos por la ley chilena.

Por el contrario, si estamos en presencia de derechos disponibles, podrá prorrogarse la competencia entre tribunales nacionales e incluso, como se ha hecho, a tribunales internacionales o de otros países.

Las materias cuyo conocimiento se entrega a la Corte Penal Internacional, por su naturaleza, son improrrogables por lo cual, para que Chile reconozca la

46 Será en primer término juez competente para conocer de los pleitos a que dé origen el ejercicio de las acciones civiles y mercantiles de toda clase, aquel a quien los litigantes se sometan expresa o tácitamente, siempre que uno de ellos por lo menos sea nacional del Estado contratante a que el juez pertenezca o tenga en él su domicilio y salvo el derecho local contrario.

Convención de Derecho Internacional Privado ("Código Bustamante"), adopción, 20 de febrero de 1928, ratificación, 6 de septiembre de 1933, Decreto 374 de 10 de abril de 1934; D.O. de 25 de abril de 1934, art. 318 inc. 1.

Son ... válidas la estipulaciones por las cuales ... se sometan diferendos derivados de . . contratos [cuyo objeto principal diga relación con negocios u operaciones de carácter económico o financiero, que se celebren por organismos, instituciones o empresas internacionales o extranjeras que tengan el centro principal de sus negocios en el extranjero, con el Estado de Chile o sus organismos, instituciones o empresas] a la jurisdicción de tribunales extranjeros, incluyendo tribunales arbitrales previstos en mecanismos de arbitraje preestablecidos o en el respectivo contrato, como también las disposiciones por las que ... se fije domicilio especial y ... se designe mandatario en el extranjero para los efectos del contrato.

D.L. 2349 , art. 1 inc. 2.

47 Cada uno de los Estados Contratantes reconocerá el acuerdo por escrito conforme al cual las partes se obliguen a someter a arbitraje todas las diferencias o ciertas diferencias que hayan surgido o puedan surgir entre ellas respecto a una determinada relación jurídica, contractual o no contractual, concerniente a un asunto que pueda ser resuelto por arbitraje.

Convención sobre el Reconocimiento y la Ejecución de las Sentencias Arbitrales Extranjeras, art. II(1); adoptada, Nueva York, 10 de junio de 1958; entrada en vigor, 7 de junio de 1959, adhesión, 4 de septiembre de 1975, Decreto de 2 de octubre de 1975, D.O. de 30 de octubre de 1975.

48 La jurisdicción del Centro [Internacional de Arreglo de Diferencias Relativas a Inversiones] se extenderá a las diferencias de naturaleza jurídica que surjan directamente de una inversión entre un Estado Contratante (o cualquiera subdivisión política u organismo público de un Estado Contratante acreditados ante el Centro por dicho Estado) y el nacional de otro Estado Contratante y que las partes hayan consentido por escrito en someter al Centro. El consentimiento dado por las partes no podrá ser unilateralmente retirado.

Convenio sobre Arreglo de Diferencias Relativas a Inversiones entre Estados y Nacionales de Otros Estados, art. 25(1), adoptado, Washington, 18 de marzo de 1965, entrada en vigor, 14 de octubre de 1966; ratificación, 24 de septiembre de 1991; Decreto 1304, de 9 de octubre de 1991; D.O. de 9 de enero de 1992 (corchetes agregados por los autores). 
jurisdicción de tribunales supranacionales deberá incorporar una nueva preceptiva constitucional a su sistema interno[.] ${ }^{49}$

Hay aquí dos argumentos a minori ad maius, uno positivo y el otro negativo. Ellos tienen la siguiente forma:

+A: Si $x$ puede lo menos, también puede lo más, y

-A: Si $x$ no puede lo menos, tampoco puede lo más.

El argumento positivo se encuentra en el segundo párrafo transcrito, y es el siguiente: quien puede prorrogar competencia entre tribunales nacionales, también puede prorrogar jurisdicción a tribunales extranjeros. Pero un argumento a minori ad maius nunca es válido cuando es positivo. En todo caso, esto no tiene importancia respecto de lo resuelto, pues solo fue dicho al pasar (obiter dictum).

Crucial en cambio en el razonamiento del Tribunal es el argumento negativo: si las partes no pueden prorrogar jurisdicción entre tribunales chilenos, menos puede el Estado prorrogar jurisdicción a tribunales extranjeros. El argumento es incorrecto porque modifica no solo el término (de mayor a menor), sino también el sujeto. Es cierto que si las partes no pueden prorrogar jurisdicción entre tribunales chilenos, menos pueden prorrogar jurisdicción a tribunales no chilenos. Pero lo que es cierto respecto de las partes no es necesariamente cierto respecto del legislador. No existe relación lógica alguna entre lo que unos u otros pueden hacer. Así, si bien ni el querellante ni el imputado o acusado en una causa criminal pueden cambiar el tribunal en que se halla radicada la misma, la ley sí pudo hacerlo. Las restricciones que encuentran las partes para elegir tribunal tienen su fuente en la ley; esta ley no obliga al legislador.

Una forma aparentemente más generosa de entender la declaración del Tribunal sería la que en vez de acentuar la estructura lógica del argumento, se concentra en los conceptos de interés público y de derechos disponibles. Desde este punto de vista, ambos conceptos constituirían categorías constitucionales que determinarían qué asuntos pueden o no pueden someterse a jurisdicciones distintas de la chilena. En lo que respecta a los derechos disponibles, la generosidad es solo aparente. En verdad cabe distinguir entre aquello que es disponible para el particular y lo que es disponible para las potestades públicas. Es cierto que las acciones penales son en buena medida indisponibles para los privados, quienes sin embargo pueden disponer de sus acciones patrimoniales (incluso las que se originan en delitos). Pero si se pretendiera que la indisponibilidad de ciertas acciones para los privados tuviera como consecuencia su igual indisponibilidad para las potestades públicas, se trataría del mismo argumento a minori ad maius recién examinado. El argumento no solo falla en términos lógicos; no se ajusta en absoluto al sentido común. Así, si bien la acción penal es en buena medida indisponible para las partes, el legislador puede dictar amnistías e indultos generales, y el Presidente de la República puede dictar indultos

${ }^{49}$ Considerando 50. 
particulares en conformidad a la ley. No cabe duda que éstos son actos de disposición legítimos cuando se cumple con los requisitos aplicables. ${ }^{50}$

Es dudoso que el interés público pueda servir como categoría constitucional útil. En todo caso, ella no sirve para distinguir adecuadamente la jurisdicción de la CPI de las jurisdicciones civiles y comerciales a que aquí se ha hecho referencia. Esto es particularmente claro, por ejemplo, respecto de la jurisdicción del Centro Internacional de Arreglo de Diferencias Relativas a Inversiones (CIADI), en el cual Chile enfrenta actualmente dos demandas. Casi por definición, todos los asuntos que llegan al CIADI son de interés público. Recientes acontecimientos de conocimiento público relativos a la defensa chilena en el asunto del diario El Clarín confirman lo anterior. Si la jurisdicción del CIADI es inconstitucional, también lo son todas las disposiciones de tratados bilaterales de promoción y protección de inversiones que reconocen el derecho de recurrir al CIADI.

Dejando de lado los problemas lógicos y conceptuales, no puede dejar de mencionarse que la pretensión de determinar los límites que afectan al legislador en la regulación de la jurisdicción conforme a las restricciones que ese mismo legislador impuso voluntariamente a los privados es simplemente insensata. El legislador es libre para modificar estas restricciones. No puede entonces pretenderse que dichas restricciones, esencialmente contingentes, definan los límites de la potestad legislativa.

\section{c) Tribunales chilenos sin reconocimiento constitucional que no pertenecen al Poder Judicial}

Existen en Chile diversos tribunales que ejercen jurisdicción a pesar de no pertenecer al Poder Judicial ni tener reconocimiento constitucional. Entre estos tribunales cabe destacar la Comisión Resolutiva Central, que ejerce jurisdicción en asuntos relativos a libre competencia, ${ }^{51}$ los directores regionales del Servicio de Impuestos Internos ${ }^{52}$ y los directores regionales y el Director Nacional del Servicio Nacional de Aduanas. ${ }^{53}$ Es cierto que estos tribunales, particularmente los directores regionales del Servicio de Impuestos Internos, a veces han estado bajo sospecha de inconstitucionalidad. Pero la razón de esta sospecha se debe principalmente a su falta de independencia o imparcialidad, no al hecho de haber sido creados por ley y no pertenecer al Poder Judicial. Esto es quizás particularmente claro respecto de la Comisión Resolutiva Central. Pues bien, el fallo del Tribunal Constitucional respecto del Estatuto de Roma de alguna manera pone en duda la constitucionalidad de la existencia de tales tribunales. Esto se debe a la ambigüedad en la norma que prohibe transferir soberanía. En la medida en que el Tribunal parece haber

50 Es cierto que la amnistía y el indulto tienen reconocimiento constitucional. Se podría luego objetar al argumento del texto que sin dicho reconocimiento explícito dichas medidas no estarían a disposición de las autoridades públicas. Sin embargo, esta objeción debiera probar que existe una esfera constitucionalmente protegida de derechos indisponibles distintos de los derechos fundamentales, pues aquí éstos no están en juego. Si bien puede ser razonable iniciar el análisis desde los derechos que el legislador tradicionalmente ha declarado indisponibles, no es legítimo al intérprete constitucional detenerse ahí. De hacerlo, estaría limitando la potestad legislativa a su ejercicio tradicional.

${ }^{5}$ D.L. 211, art. 17, D.O. de 22 de diciembre de 1973.

52 Decreto Ley 830, Código Tributario, D.O. de 31 de diciembre de 1974, arts. 6(B) No 6 y 115; Decreto con Fuerza de Ley 7 (Hacienda), Ley Orgánica del Servicio de Impuestos Internos, D.O. de 15 de octubre de 1980, art. 19(b).

${ }^{53}$ Decreto 329 de 16 de abril de 1979 (Hacienda), Ley Orgánica del Servicio Nacional de Aduanas, D.O. de 20 de junio de 1979 , art. $4 \mathrm{~N}^{\circ} 12$ y No 16 y art. $15 \mathrm{~N}^{\circ} 6$. 
articulado un concepto de soberanía que distribuye competencias entre constituyente por una parte, y legislador o autor de tratados internacionales por la otra, lo que no se puede transferir al extranjero tampoco podría transferirse a órganos internos salvo, por cierto, que éstos tuvieran reconocimiento constitucional. Sabemos que tratándose de tribunales del Poder Judicial este problema no se presenta, porque la regla especial del artículo 73 autoriza su creación mediante ley. Pero aquellos tribunales sin reconocimiento constitucional que no pertenecen al Poder Judicial estarían ejerciendo funciones soberanas en infracción del Art. $5^{\circ}$ de la Constitución Política.

Para evitar esta consecuencia habría dos argumentos posibles. El primero consistiría en negar que los tribunales de que aquí se trata ejercen jurisdicción. Pero éste es un camino cerrado por la propia definición de jurisdicción que usa el Tribunal Constitucional. El segundo consistiría en articular una prohibición de transferencia de soberanía al exterior distinta de la prohibición de transferencia de soberanía interna. Eso obligaría a fundar la primera en una disposición distinta del Art. $5^{\circ}$. Es probable que la mejor regulación de este problema exija una reforma constitucional, pues el Tribunal Constitucional no se ha mostrado capaz de darle solución dogmática.

\section{B. Transferencia de potestad legislativa para declarar indultos y amnistías generales}

En opinión del Tribunal, que siguió en esto al Conseil Constitutionnel francés, la jurisdicción de la CPI también importa transferencia de potestad legislativa para declarar indultos y amnistías generales:

[L]os artículos [17(1)(a) y 110] del Estatuto de Roma . . . son incompatibles con las normas constitucionales anteriormente citadas [art. $60 \mathrm{~N}^{\circ} 16$ ], toda vez que, de una comparación de los textos transcritos resulta que el Estatuto infringe claras normas constitucionales, pues, en esencia, ... priva al órgano legislativo de su facultad de dictar leyes sobre indultos generales y amnistías, en relación con los ilícitos contemplados en el artículo $5^{\circ}$ del Estatuto de la Corte Penal Internacional.

Este quebrantamiento constitucional se produce en razón que la Corte Penal Internacional podría desconocer en sus sentencias indultos o amnistías previamente concedidas por las autoridades nacionales competentes;

[L]a sentencia del Consejo Constitucional Francés que declaró que para ratificar la Convención sobre el Estatuto de la Corte Penal Internacional era necesaria una revisión constitucional, tuvo en especial consideración que, de acuerdo con el Estatuto, una causa podía ser sometida válidamente ante la Corte Penal Internacional por la sola circunstancia de la aplicación de la ley de amnistía, lo que obligaría a Francia a entregar a una persona por hechos que estarían cubiertos por dicha amnistía. En estas circunstancias, se estimó que se estaría atentando contra las condiciones esenciales del ejercicio de la soberanía nacional;

[E]1 mismo argumento es dable utilizar tratándose de la aprobación del Tratado de Roma en nuestro país, pues los artículos del Estatuto antes señalados violan claras disposiciones constitucionales y, en consecuencia, atentan contra el ejercicio de la 
soberanía nacional por el órgano colegislador y por el Presidente de la República, conculcando el artículo $5^{\circ}$, inciso primero, de nuestra Ley Fundamental[.] ${ }^{54}$

Es evidente que al reconocer la jurisdicción de la CPI el Estado en cierto modo afecta su potestad para dictar indultos generales y amnistías. Sin embargo, ni es correcta la afirmación en el sentido de que el Estado renuncia o transfiere dicha potestad, ni resulta obvio que tal renuncia o transferencia, de existir, fuera inconstitucional. En primer lugar, al declarar que el Estatuto de Roma "priva al órgano legislativo de su facultad de dictar leyes sobre indultos generales y amnistías, en relación con los ilícitos contemplados en el artículo $5^{\circ}$ del Estatuto de la Corte Penal Internacional", el Tribunal Constitucional confunde la potestad legislativa para dictar dichos indultos y amnistías con sus efectos en jurisdicciones distintas de la chilena. No hay disposición alguna del Estatuto que prohiba al Estado decretar indultos generales o amnistías. Una ley que así lo hiciera sería perfectamente válida y tendría plenos efectos en tribunales chilenos. Es cierto sin embargo que tal ley podría ser tomada por la CPI como prueba de la ausencia de disposición para investigar y juzgar, lo que justificaría que entrara a conocer de los casos cubiertos por dicha ley. Lo verdaderamente problemático de esta situación es que las autoridades chilenas podrían verse obligadas a entregar a la CPI, en virtud del artículo 89(1) del Estatuto, personas que han sido beneficiadas con indultos generales o amnistías. De modo indirecto, esta obligación incide en la potestad legislativa para declarar tales indultos y amnistías.

¿Es inconstitucional esta afectación incidental de la potestad legislativa? Concediendo que en virtud del tratado el legislador renuncia completamente a su potestad para declarar indultos generales y amnistías respecto de los crímenes de genocidio, de lesa humanidad y de guerra, ¿sería tal renuncia inconstitucional? En opinión del Tribunal es evidente que sí. Sin embargo, es obvio que muchos tratados internacionales disminuyen el ámbito de autonomía legislativa y que no por eso son inconstitucionales. El Tribunal cree que el efecto del Estatuto sobre la potestad legislativa infringe el Art. $5^{\circ}$ inciso primero de la Constitución Política.

Si se acepta la tesis de que toda restricción de la potestad legislativa importa una renuncia o transferencia de soberanía vedada al legislador, no habría prácticamente tratado internacional alguno que pudiera ratificarse sin previa reforma constitucional. Considérese por ejemplo el tratado que creó a la Organización Mundial del Comercio (OMS). Este tratado ha reducido significativamente la potestad legislativa para "imponer, suprimir, reducir o condonar tributos de cualquier clase o naturaleza, establecer exenciones o modificar las existentes y determinar su forma, proporcionalidad o progresión." (art. 62 inc. $4 \mathrm{~N}^{\circ} 1$ en relación con el art. $60 \mathrm{~N}^{\circ}$ 14). El 15 de junio de 1999 un panel de la OMS falló que la Ley 19.534 de 13 de noviembre de 1997 es contraria al artículo III:2, segunda oración, del GATT $1994 .{ }^{55}$ El 23 de mayo de 2000 se dio plazo al Estado de Chile hasta el día 21 de marzo de 2001 para adecuar su legislación de alcoholes al GATT 1994.56 Pues bien, si el Estatuto de Roma es inconstitucional porque afecta la potestad legislativa para

\footnotetext{
${ }^{54}$ Considerandos 79 a 81.

55 Organización Mundial del Comercio, Informe del Grupo Especial, Chile - Impuestos a las Bebidas Alcohólicas, WT/DS87/R, W'T/DS110/R, 15 de junio de 1999, confirmado, Órgano de Apelación, WT/DS87/AB/R, WT/DS/110/AB/R, 13 de diciembre de 1999.

56 Organización Mundial del Comercio, Laudo del Árbitro, Chile - Impuestos a las Bebidas Alcohólicas, WT/DS87/15, WT/DS110/14, 23 de mayo de 2000.
} 
dictar amnistías e indultos generales, igualmente inconstitucional sería el tratado que creó la OMS, en cuanto afecta la potestad legislativa para regular los tributos. Los ejemplos podrían multiplicarse. Es de ordinaria ocurrencia que las obligaciones convencionales del Estado de Chile tengan por efecto una reducción del ámbito de ejercicio de sus potestades legislativas. Nunca se ha pensado que por esa razón la aprobación de un tratado internacional requiera reforma constitucional.

Distinto sería si el Tribunal hubiera argumentado que la potestad legislativa para declarar amnistías o indultos generales tuviera una calidad distinta de las demás potestades legislativas, tal que su afectación por un tratado internacional fuera inconstitucional. Sin embargo, ni el Tribunal argumentó en este sentido, ni puede verse de qué modo tal argumentación podría haberse justificado en la Constitución Política. Además, ella también importaría la inconstitucionalidad de compromisos contraídos por el Estado de Chile con anterioridad y que tienen por efecto, aun más que el Estatuto, restringir la potestad del Estado de Chile para amnistiar o indultar ciertos delitos. Tal es el caso de las prohibiciones de autoexoneración establecidas en los convenios de Ginebra citados en nota a pie página 36.

\section{Transferencia de potestad presidencial para conceder indultos particulares}

El Tribunal estimó que al igual que la potestad legislativa para dictar leyes de indulto general y amnistía, la potestad presidencial para conceder indultos particulares también se oponía a la jurisdicción de la CPI:

[L]os artículos [17(1)(a) y 110] del Estatuto de Roma . . . son incompatibles con las normas constitucionales anteriormente citadas [art. $32 \mathrm{~N}^{\circ} 16$ ], toda vez que, de una comparación de los textos transcritos resulta que el Estatuto infringe claras normas constitucionales, pues, en esencia, coarta las atribuciones del Presidente de la República para dictar indultos particulares . . . en relación con los ilícitos contemplados en el artículo $5^{\circ}$ del Estatuto de la Corte Penal Internacional.

Este quebrantamiento constitucional se produce en razón que la Corte Penal Internacional podría desconocer en sus sentencias indultos o amnistías previamente concedidas por las autoridades nacionales competentes;

$\cdots$

[L]os artículos del Estatuto antes señalados violan claras disposiciones constitucionales y, en consecuencia, atentan contra el ejercicio de la soberanía nacional ... por el Presidente de la República, conculcando el artículo 5º inciso primero, de nuestra Ley Fundamental[. $]^{57}$

Si el argumento de que la potestad legislativa relativa a indultos y amnistías se contradice con la potestad de la CPI tenía poca plausibilidad, este nuevo argumento no tiene ninguna. El Presidente de la República tiene potestad para "otorgar indultos particulares en los casos y formas que determine la ley." Un tratado internacional es, para estos efectos, equivalente a una ley. Nada impide que mediante un tratado internacional se restrinja los casos en que el Presidente de la República puede conceder indultos. Es lamentable que el Tribunal Constitucional haya pasado por alto algo tan obvio.

57 Considerandos 79 a 81. 


\section{Conclusión}

La decisión del Tribunal tiene como consecuencia elevar el quórum necesario para aprobar el Estatuto de Roma, el que ahora alcanza a los tres quintos de diputados y senadores en ejercicio. En una república constitucional democrática debe ofrecerse una justificación para la exigencia de un quórum supramayoritario para la producción de normas generales. Los derechos fundamentales proveen dicha justificación frente a normas generales que los afectan de un modo incompatible con la protección concretamente dispensada por la Constitución. Otras veces son consideraciones de orden político las que otorgan dicha justificación. Así, en Estados Unidos el quórum de dos tercios exigido para que el Senado dé su consentimiento a un tratado internacional se justifica (o se justificaba en 1787) en que mediante un tal tratado una mayoría de estados podía sacrificar los intereses de una minoría de estados. No extraña entonces constatar que junto con disminuir la identidad de los distintos estados y aumentar la del país en su totalidad se haya recurrido cada vez a un modo alternativo y mayoritario de aprobación interna de los tratados internacionales que elude la exigencia constitucional de un quórum supramayoritario en el Senado. ${ }^{58}$

Hacia el final del fallo comentado en este trabajo, el Tribunal Constitucional declaró que:

si se aceptara bajo el texto actual de la Ley Fundamental Chilena, la Corte Penal Internacional, ello implicaría una violación a normas de rango constitucional y no se debe olvidar que hoy se acepta universalmente que la gran garantía de los derechos fundamentales es la Constitución -concepción garantista de la Constitución-, de manera que la violación de la Carta Política viene a significar en último término, la desprotección de los derechos[.]

Esta declaración es paradójica. En ella el tribunal justifica finalmente la declaración de inconstitucionalidad del Estatuto en la protección de los derechos fundamentales. Pero en ningún momento de su fallo analiza el Tribunal en qué modo el Estatuto podría afectar dichos derechos. A pesar de la declaración transcrita, son razones puramente orgánicas las que llevaron a la declaración de inconstitucionalidad, y razones que carecen de una justificación de justicia política como la que existe o existía en Estados Unidos. Resulta inaceptable que un tribunal constitucional occidental recurra a una retórica de derechos fundamentales sin darles lugar alguno en su razonamiento. Es particularmente inaceptable porque el Estatuto de Roma presenta problemas considerables a la luz de los dichos derechos, al menos en relación con los principios nullum crimen sine lege y ne bis in idem. Estas consideraciones no recibieron atención alguna por parte del Tribunal.

El Estatuto de Roma presenta desafíos constitucionales de envergadura para cualquier tribunal constitucional. La Corte Penal Internacional es una institución sin parangón en los tiempos modernos, de difícil complementación con las judicaturas estatales, y con diversas características que hace dudar de su constitucionalidad. Es posible que frente a este desafío muchos de los tribunales que en distintos países han tenido que pronunciarse sobre dicho tratado hayan hecho un análisis deficiente del Estatuto. Sólo la

58 Ackerman y Golove, Is NAFTA Constitutional? 
crítica fundada a dichos análisis permitirá mejorar la doctrina constitucional en un área que probablemente seguirá planteando nuevos problemas. El Tribunal Constitucional es en este sentido blanco legítimo de la crítica como pocos.

A lo largo de este comentario se ha puesto acento en los numerosos problemas que enfrenta su argumentación y las consecuencias negativas que su universalización acarrearía. Es sin embargo poco probable que esas consecuencias negativas de hecho se sigan. Pero eso no se debe a que las razones expuestas por el Tribunal no sean tan problemáticas como aquí se ha sostenido. Se debe más bien a que ellas no serán tomadas en serio por la comunidad jurídica chilena. Esto conduce a un estado de cosas lamentable.

Mientras los órganos constitucionales no generen una doctrina constitucional sólida que pueda dar lugar a razones universales no existirá en Chile un derecho constitucional que de verdad constituya un marco de referencia de contornos relativamente bien definidos dentro del cual se desarrolle una política civilizada. 